\title{
A case for hornblende dominated fractionation of arc magmas: the Chelan Complex (Washington Cascades)
}

\author{
Mathias Dessimoz • Othmar Müntener • \\ Peter Ulmer
}

Received: 2 December 2010/Accepted: 26 August 2011/Published online: 4 October 2011

(C) Springer-Verlag 2011

\begin{abstract}
Amphibole fractionation in the deep roots of subduction-related magmatic arcs is a fundamental process for the generation of the continental crust. Field relations and geochemical data of exposed lower crustal igneous rocks can be used to better constrain these processes. The Chelan Complex in the western U.S. forms the lowest level of a 40-km thick exposed crustal section of the North Cascades and is composed of olivine websterite, pyroxenite, hornblendite, and dominantly by hornblende gabbro and tonalite. Magmatic breccias, comb layers and intrusive contacts suggest that the Chelan Complex was build by igneous processes. Phase equilibria, textural observations and mineral chemistry yield emplacement pressures of $\sim 1.0 \mathrm{GPa}$ followed by isobaric cooling to $700^{\circ} \mathrm{C}$. The widespread occurrence of idiomorphic hornblende and interstitial plagioclase together with the lack of Eu anomalies in bulk rock compositions indicate that the differentiation is largely dominated by amphibole. Major and trace element modeling constrained by field observations and
\end{abstract}

Communicated by T. L. Grove.

Electronic supplementary material The online version of this article (doi:10.1007/s00410-011-0685-5) contains supplementary material, which is available to authorized users.

\author{
M. Dessimoz $(\square) \cdot$ O. Müntener \\ Insitut de Minéralogie et Géochimie, Université de Lausanne, \\ 1015 Dorigny, Switzerland \\ e-mail: mathias.dessimoz@unil.ch \\ O. Müntener \\ e-mail: othmar.muntener@unil.ch \\ P. Ulmer \\ Department of Earth Sciences, ETH Zurich, \\ Clausiusstrasse, 25, 8092 Zurich, Switzerland \\ e-mail: peter.ulmer@erdw.ethz.ch
}

bulk chemistry demonstrate that peraluminous tonalite could be derived by removing successively $3 \%$ of olivine websterite, $12 \%$ of pyroxene hornblendite, $33 \%$ of pyroxene hornblendite, $19 \%$ of gabbros, $15 \%$ of diorite and $2 \%$ tonalite. Peraluminous tonalite with high $\mathrm{Sr} / Y$ that are worldwide associated with active margin settings can be derived from a parental basaltic melt by crystal fractionation at high pressure provided that amphibole dominates the fractionation process. Crustal assimilation during fractionation is thus not required to generate peraluminous tonalite.

Keywords Chelan Complex - Amphibole fractionation . Adakite $\cdot$ Continental crust $\cdot$ Volcanic arc $\cdot$ North Cascades

\section{Introduction}

The trace and major element composition of the continental crust (Taylor and McLennan 1985; Rudnick and Gao 2003) show wide similarities with actual calc-alkaline lavas (e.g., enrichment in light rare earth element (LREE), depletion in $\mathrm{Nb}$, Ta and $\mathrm{Ti}$ and enrichment of $\mathrm{Pb}$ with respect to the REE) suggesting that subduction zone and active margin settings are the most important places where new continental crust is formed (Rudnick 1995). However, the bulk composition of some island arcs and thus the mass flux out of the mantle in subduction zone is basaltic $\left(\mathrm{SiO}_{2}<52\right.$ wt\%) (e.g., DeBari and Sleep 1991), whereas the bulk composition of the continental crust is andesitic $\left(\mathrm{SiO}_{2}\right.$ about $60 \mathrm{wt} \%$ ) (Taylor and McLennan 1985; Rudnick and Gao 2003) due to the presence of large amounts of intermediate to granitic rocks in the upper crust. This leads to the important question on how arcs evolve after accretion and which processes in the upper mantle and lower crust 
are the most important ones to produce evolved magmas. These processes are still controversial, and different hypotheses are proposed: (1) partial melting of preexisting basaltic crust producing primary andesitic liquids (Atherton and Petford 1996); (2) crystal fractionation of primitive hydrated basalt leaving low $\mathrm{SiO}_{2}$ cumulates at the crust mantle boundary or in the lower crust (Greene et al. 2006; Müntener and Ulmer 2006; Jagoutz 2010). Due to density difference, arc cumulates may return to the mantle by delamination (Kay and Kay 1985, 1991, 1993; Jull and Kelemen 2001) progressively driving the crust toward an andesitic composition; (3) in continental arcs, partial melting, assimilation and mixing between primitive, mantle-derived basaltic melts and granitic melts might form andesite (Hildreth and Moorbath 1988).

Partial melting of the mantle wedge in convergent margin settings requires high amounts of volatile input $\left(\mathrm{H}_{2} \mathrm{O}\right.$ or supercritical hydrous liquids) released from the down-going slab (Tatsumi 1989; Ulmer and Trommsdorff 1995; Grove et al. 2002; Kelemen et al. 2003; Kessel et al. 2005) generated by dehydration of sediments, hydrated basalt or serpentinite resulting in hydrous basaltic melts. Because $\mathrm{H}_{2} \mathrm{O}$ is an important component of subductionrelated magmas (up to $10 \mathrm{wt} \%$ ) (Grove et al. 2002; Pichavant et al. 2002), numerous experiments were performed at different pressures and variable amounts of water to understand the effect of $\mathrm{H}_{2} \mathrm{O}$ on the differentiation at similar conditions expected for subduction zones (Sisson and Grove 1993a, b; Müntener et al. 2001; Kägi 2000; Feig et al. 2006; Alonso-Perez et al. 2009). The addition of $\mathrm{H}_{2} \mathrm{O}$ has a number of important effects on phase relations in magmas. It reduces the stability field of plagioclase relative to ferromagnesian minerals (ol-hbl-cpx-gt), stabilizes anorthite-rich (silica poor) plagioclase (Sisson and Grove 1993a) and leads to an expansion of the primary phase volume of olivine (e.g., Kushiro et al. 1968). $\mathrm{H}_{2} \mathrm{O}$ in magmatic liquids stabilizes Ca-rich clinopyroxene and amphibole at intermediate to lower crustal pressures relative to opx and plagioclase, and garnet becomes increasingly important at pressures exceeding $\sim 0.8 \mathrm{GPa}$ (Alonso-Perez et al. 2009). Moreover, field observations of the rare exposure of lower crust and crust/mantle transition zones such as Kohistan Arc Complex, Pakistan (Burg et al. 1998; Ringuette et al. 1999) and the Alaskan Talkeetna arc (DeBari and Coleman 1989; Greene et al. 2006) as well as crust and mantle xenoliths (Ducea and Saleeby 1996, 1998) provide evidence that garnet may play a significant role in the differentiation of basaltic magmas at the base of thick arc or continental crust. At intermediate pressure, amphibole is an important phase controlling the fractionation of hydrous basalt (Grove et al. 2002; Sisson et al. 2005). However, looking at arc mafic lavas reaching the surface, amphibole phenocrysts are often rare (Davidson et al.
2007; Macpherson 2008), while geochemical arguments mainly based on trace elements point to an important role of amphibole fractionation in the volcanic suite (e.g., Cawthorn et al. 1973; Arculus and Wills 1980; Davidson et al. 2007; Ulmer 2007). Therefore, igneous amphibole should be present in large amounts and retained somewhere in plutonic roots of island arc crust (Larocque and Canil 2010; Jagoutz 2010).

The association of ultramafic (peridotite-pyroxenitehornblendite), mafic and silicic rocks is common in deepseated subduction-related plutonic rocks such as in the Adamello (e.g., Ulmer 2007), in Talkeetna (e.g., DeBari and Coleman 1989) or in Kohistan (e.g., Burg et al. 1998). This common association was often interpreted as a result of prograde metamorphism and partial melting due to the destabilization of amphibole (Petford and Atherton 1996) or as the result of high-pressure crystallization of primitive magma (DeBari and Coleman 1989; Ringuette et al. 1999; Ulmer 2007). Because the Chelan Complex in central Washington forms part of a continental arc and exposes evolved plutonic rocks intimately associated with olivine websterite, pyroxenite, hornblendite and gabbros, it provides a unique opportunity to understand the relation between silicic and ultramafic plutonic rocks and may help to understand the processes occurring at the base of actual arcs. To evaluate between remelting of preexisting crust and fractional crystallization and to clarify the role of amphibole in the generation of calc-alkaline lavas field observations, geochemical analyses, and major and trace element modeling were performed.

\section{Geological setting}

The North Cascades crystalline ore is exposed at the southern end of the $1,500 \mathrm{~km}$ long coast plutonic complex that extends from southern Alaska to central Washington state (Fig. 1a). The coast belt was formed during the final stage of accretion of the insular superterranes against North America (e.g., Rubin et al. 1990; Journeay and Friedman 1993) and preserves a section of crust from mid crustal rocks to $40 \mathrm{~km}$ deep rocks (Miller et al. 2000; Miller and Paterson 2001) that records Cretaceous to Palaeogene arc magmatism and greenschist to amphibolite facies regional metamorphism (Rubin et al. 1990). The coast mountains underwent SW-NE contraction and crustal thickening during the Late Cretaceous (Rubin et al. 1990; Umhoefer and Miller 1996; Paterson et al. 1998) (<96-73 Ma), which correspond to the arc building stage. The compression was followed by early Tertiary transpression (73-58 Ma) and transtension (55-45 Ma) (Valley et al. 2003).

The North Cascades Core is bound to the west and the northeast by high-angle Tertiary faults (Tabor et al. 1987), 


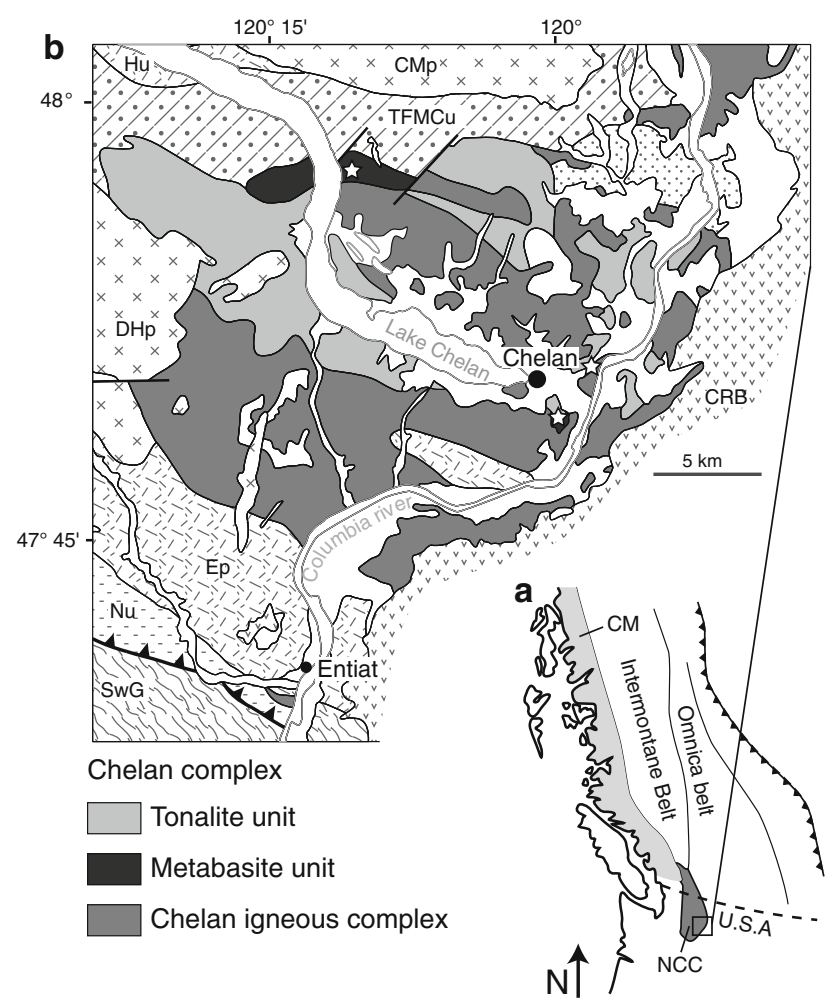

Fig. 1 a Map of western North America showing the position of the North Cascades Core (NCC) in dark gray relative to the coast mountain belt (CM) in light gray (modified after Whitney et al. 1999); b Geological map of the Chelan Complex simplified after Hopson and Mattinson (1994). The white stars indicate the locality of the largest outcrops of ultramafic rocks within the Chelan Complex. Abbreviation used in the Figure: $N u$ Napeequa unit, $H u$ Holden unit, $T F M u$ Twenty-five miles creek unit, $S w G$ Swakane Gneiss, Ep Entiat pluton, $D H p$ Duncan Hill pluton, $C M p$ Copper mountain pluton, $C R B$ Columbia river basalt

the Straight Creek Fault and the Ross Lake Fault (Gordon et al. 2010), respectively. The Entiat fault, the major internal structure, separates the North Cascades Core in the Wenatchee block on the west and the Chelan block on the east, which presents a slightly different metamorphic history (Valley et al. 2003). The Chelan block is composed by a mixture of Palaeozoic supracrustal rocks (Cascade Holden River assemblage, Napeequa Twisp Valley assemblage, Swakane gneiss, Skagit gneiss) and numerous plutons of different ages ranging from Cretaceous to early Miocene (Tabor et al. 1987). Thermobarometric data from the Swakane Gneiss and Napeequa complex indicate that the Chelan block was metamorphosed at upper amphibolite facies conditions at pressures of 1.0-1.2 GPa and a temperatures of $640-750^{\circ} \mathrm{C}$ (Brown and Walker 1993; Valley et al. 2003; Gordon et al. 2010) before $96 \mathrm{Ma}$ (Wernicke and Getty 1997; Valley et al. 2003; Gordon et al. 2010). The emplacement depths of the plutons vary between 0.7 GPa and shallower levels.
The Chelan Migmatite Complex (CMC), defined by Hopson and Mattinson (1994), crops out along the lower lake of Chelan, the Chelan River and adjacent area along the Columbia River (Fig. 1b) at the southern end of the Chelan block (Haugerud et al. 1991). It consists mainly of early Cretaceous metatonalite, metaplutonic migmatite, migmatitic amphibolite and hornblendite (Hopson and Mattinson 1994). The CMC is the oldest member of the plutonic rocks within the Chelan block emplaced during early Cretaceous (120-100 Ma) (Mattinson 1972). The contact relationships between the CMC and the PaleozoicMesozoic rocks are not well exposed except at the northern boundary. The border of the complex deflects abruptly close to the contact with the 25 Miles Creek unit (Hopson and Mattinson 1994), which separates the CMC from the Skagit gneiss. Close to the contact of the CMC, the supracrustal rocks are invaded by leucosomes indicating that the CMC is intrusive in the supracrustal rocks. To the east/ southeast, the complex disappears beneath the Columbia River Basalt (Fig. 1b). To the West, the contact is partially obliterated by the younger Entiat pluton emplaced between 78 and $60 \mathrm{Ma}$ (north of Entiat see, Fig. 1). However, a small outcrop of the CMC lies between the Entiat pluton (south of Entiat see Fig. 1b) and the Napeequa unit suggesting a primary intrusive contact between the Chelan Complex and the Napeequa unit (Fig. 1b) (Hopson and Mattinson 1994).

\section{Field observations and petrography}

A summary of field relationships and detailed descriptions of various units has been given by Hopson and Mattinson (1994). Here, we add new field observations, with emphasis on the ultramafic and mafic units.

\section{Ultramafic rocks (peridotite, pyroxenite, hornblendite)}

Ultramafic rocks are widespread throughout the Chelan Complex (Fig. 2a) and vary from coarse grained hornblendites, (meta) pyroxenites and a few olivine hornblende websterites.

In a few places (north of Chelan Lake, Knappe Navarre Coulee, Chelan gorge), ultramafic rocks form (kilo) meter scale magmatic breccias that are composed of hundreds of mostly angular blocks of ultramafic rocks separated by tonalite, pegmatitic gabbros or by deformed diorite/tonalite (Fig. 2a). The predominance of angular blocks over rounded ones and contact relationships indicates that most of the ultramafic rocks were intruded by tonalite and gabbros (Fig. 2a).

Olivine websterite is composed of variable proportions of olivine, orthopyroxene, clinopyroxene and amphibole 

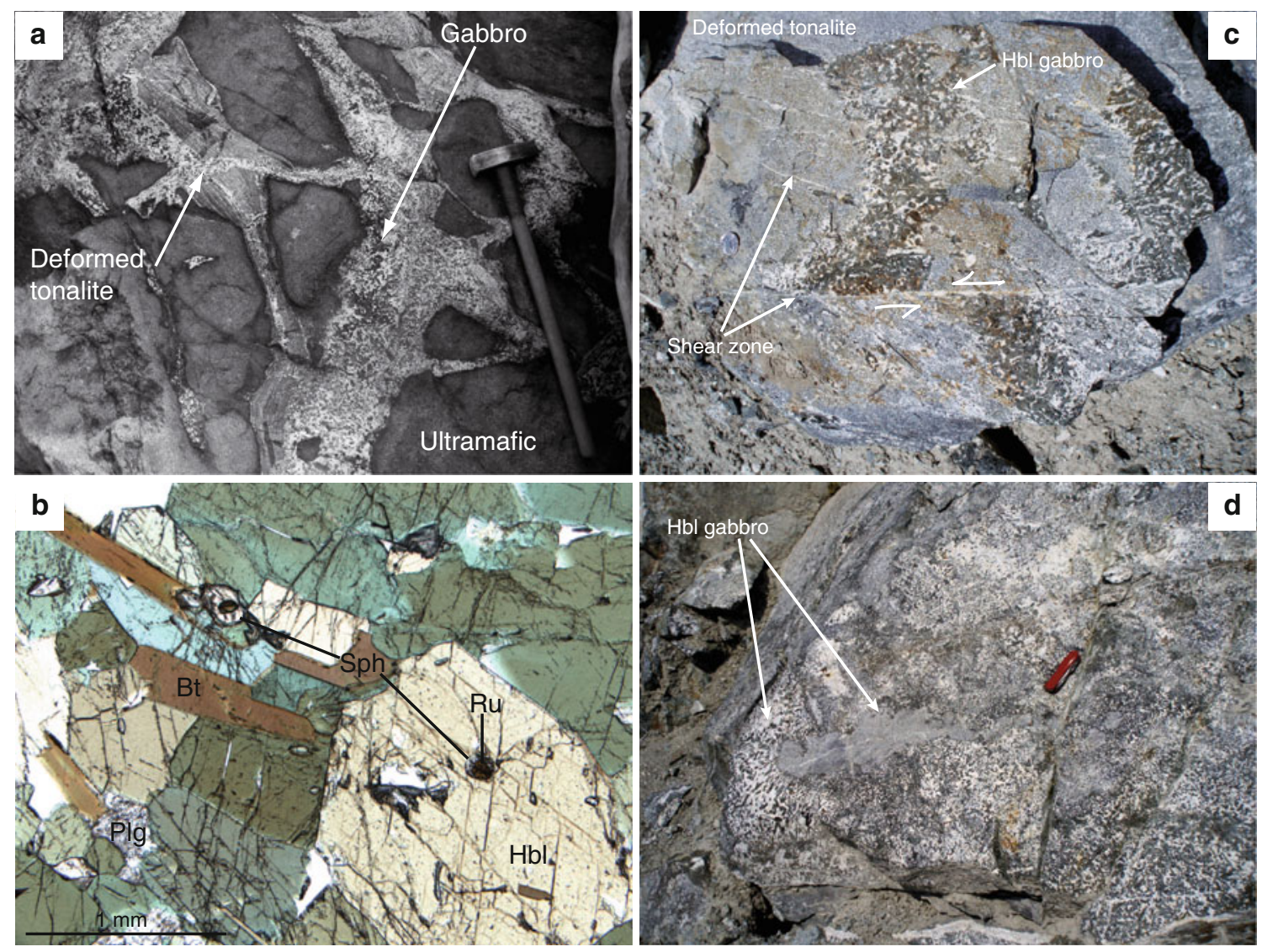

Fig. 2 Field photographs and thin section micrographs of a Ultramafic blocks cut by pegmatitic gabbros and deformed tonalite, Chelan gorge; b Typical texture of hornblendites, with large euhedral crystals of hornblende (hbl, approximately $1 \mathrm{~mm}$ ), few biotites (bt), interstitial plagioclase (plg) and minor rutile (ru) and sphene (sph). Euhedral

(e-table 1). Olivine may be absent in some samples. Spinel, plagioclase and magnetite are present in minor amount. Olivine is subhedral and displays fractures filled with opaque minerals and serpentine. Symplectitic intergrowths of spinel and orthopyroxene are present at the border of olivine. Clinopyroxene is anhedral and partially replaced by amphibole along cleavages and borders indicating reaction relationships between hornblende and clinopyroxene. Pinkish orthopyroxene is much less abundant than clinopyroxene and is sometimes serpentinized along the cleavages. Amphibole is interstitial and partially grows at the expense of clinopyroxene. Plagioclase is rarely observed and is always surrounded by amphibole and symplectitic intergrowth of green spinel and clinopyroxene indicating destabilization of plagioclase during cooling.

Only a few meter size pyroxenite bodies are found in the Chelan Complex. They are composed of orthopyroxene, clinopyroxene and amphibole (e-table 1). Pinkish orthopyroxene $(<2 \mathrm{~cm}$ in diameter) exhibits tiny exsolution of the complementary pyroxene and is partially or totally replaced by talc. Orthopyroxene and clinopyroxene are hornblende indicates cumulate texture; $\mathbf{c}$ Pegmatitic gabbros embayed in deformed tonalite. Shear zones filled with silicic melt sheared the gabbro; $\mathbf{d}$ Mingling between different gabbros. The texture of gabbros varies from pegmatitic to fine grained gabbros

interfingered indicating cotectic crystallization. Interstitial amphibole displays brownish cores with relicts of clinopyroxene and $\mathrm{Fe}-\mathrm{Ti}$ oxides in the core and are sometimes surrounded by a narrow rim of green hornblende indicating that some of the amphiboles grew at the expense of clinopyroxene.

Hornblendite is mainly composed by coarse idiomorphic green amphibole and interstitial plagioclase together with minor biotite, rutile, sphene and magnetite (e-table 1) (Fig. 2b). K-feldspar is rare and may be present as interstitial phase. Euhedral hornblende indicates cumulus textures (Fig. 2b); however, reaction textures with relicts of clinopyroxene are often observed. Numerous inclusions of tiny ilmenite crystals are observed in the core. Biotite and borders of amphibole are partially replaced by chlorite.

\section{Mafic rocks (gabbros and diorite)}

Gabbros, pegmatitic gabbros and diorite are present as matrix phase around ultramafic rocks especially in the Chelan gorge (Fig. 2a, c, d) and thus clearly postdate the 
emplacement of ultramafics. Enclaves of gabbros are widespread in the tonalite and in the Chelan Igneous Unit. In the Chelan gorge, tonalite and gabbros show mingling textures with pockets of tonalite enclosed in the gabbros (Fig. 3a). Numerous intrusive features and interfingered contacts between fine grained and coarse grained gabbros could be observed in the Chelan gorge (Fig. 2d).

The texture of mafic rocks varies from microgabbros to pegmatitic gabbros (hornblende up to few centimeters) (Fig. 2c, d) with acicular idiomorphic green amphibole and interstitial plagioclase. In a few samples, porphyritic crystals of hornblende are replaced by a small amphibole crystals or are partially chloritized. Some crystals are poikilitic and rich in quartz inclusions indicating that hornblende is a reaction product. Partially, sericitized plagioclase is homogeneous with only rare zonations preserved. Euhedral biotite is a major phase and is often replaced by chlorite. Ilmenite, sphene, rutile and apatite are present as accessory minerals in some samples (e-table 1). Ilmenite and rutile are often rimmed by sphene. Some rare gabbros contain clinopyroxenes and late magmatic epidote. Epidote shows vermicular intergrowth with quartz and grows at the expense of hornblende. Occasionally, rare allanite-rich cores indicate a magmatic origin of epidote (Zen and Hammarstrom 1984, 1986; Zen 1985). In some samples, quartz is present as a minor phase $<10 \%$.

Tonalite

The volumetrically most important lithology of the Chelan Complex is tonalite covering an area of over $100 \mathrm{~km}^{2}$ (Hopson and Mattinson 1994). A pervasive foliation is locally developed inside the tonalite giving rise to a gneissic aspect. The general lack of deformed quartz and biotite indicates that the foliation may be of magmatic origin. Schlieren and comb layer textures (Fig. 3b) are observed within the tonalite. Mingling with gabbros is common in the Chelan gorge (Fig. 3a). From field observations, it appears that gabbros and tonalite were emplaced simultaneously. Several pulses of tonalite are observed in the field with complicated mixing or mingling textures and crosscutting relationships (Fig. 3b). Tonalite is cut by late lamprophyric, composite mafic to dioritic and pegmatitic dikes.

Tonalite displays a large range in grain size, from coarse grained leucotonalite to fine grained (mela-) tonalite. It is
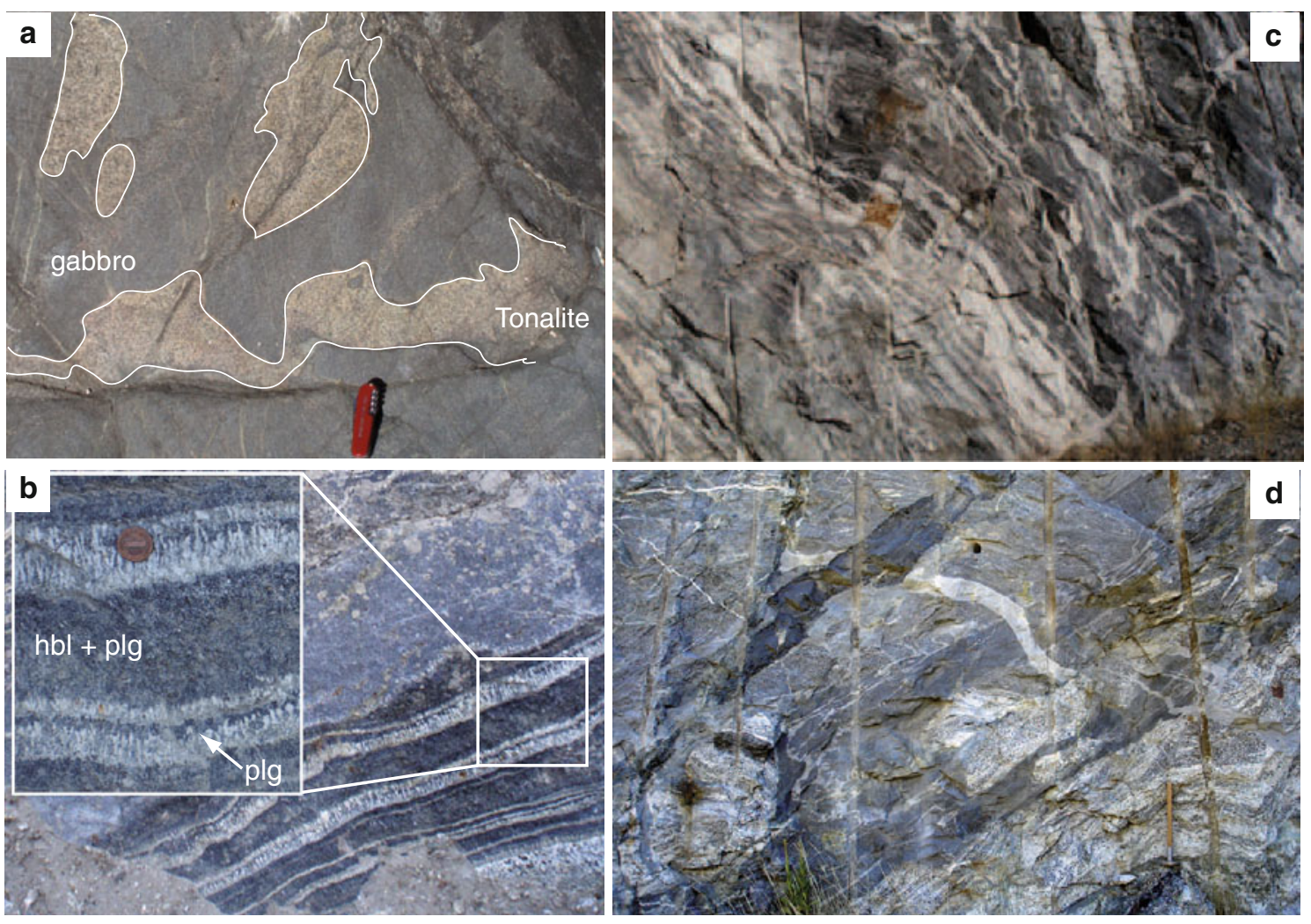

Fig. 3 Field photographs of a Mingling between tonalite and gabbros showing interlobate contact, Chelan gorge; b Comb layer inside tonalite representing repeated changes in crystallization sequence between plagioclase and amphibole; c Alternation of decimetric to metric scale white layers (mainly tonalite) and dark layers (mela-

tonalite, gabbros). The felsic layers are folded and discontinuous indicating flow and concentration of deformation in this zone; d Multiple injections of leuco and mela-tonalite within the Chelan Igneous unit 
composed of plagioclase, hornblende, biotite, sphene, quartz, apatite, $\mathrm{Fe}-\mathrm{Ti}$ oxide, epidote and rare muscovite $(<1 \%)$ (e-table 1). Hornblende may be locally absent in the most evolved members. Biotite is partially chloritized and displays vermicular intergrowth with quartz in some samples. Plagioclase is generally fresh without visible zonation. In fine grained tonalite, however, normal zoning with anorthite-rich cores is observed. Epidote with euhedral to subhedral allanite cores is often intergrown with quartz. It is idiomorphic in contact with biotite and xenomorphic in contact with quartz and plagioclase. Textural observations are in agreement with a magmatic origin of epidote indicating pressure of crystallization higher than $\sim 0.5-0.6$ GPa (Zen and Hammarstrom 1984, 1986; Zen 1985).

Chelan Igneous unit (Migmatite unit of Hopson and Mattinson (1994)) ${ }^{1}$

The Chelan Igneous Unit exposes millimetric to decimetric alternations of mesocratic and leucocratic layers (Fig. 3c, d). At the outcrop scale, the Chelan Igneous Unit is very chaotic and obviously deformed (Fig. 3c). The contact between the Chelan Igneous Unit and tonalite or gabbro is not always well defined in the field and appears to be gradational. Folds, pervasive foliation and shear zones are very common (Fig. 3c). However, multiple primary intrusive contacts are preserved, indicating that a significant part of the Chelan Igneous Unit is a product of multiple injections of several liquids in variable proportions (Fig. 3c, d). Mingling textures are commonly observed with tonalite-derived plagioclase and quartz incorporated in gabbros or other tonalite. Numerous syn-magmatic shear zones cutting the banding are filled by felsic melt. Similar observations can be made for melt-filled fractures that are discordant to the foliation. Areas with high proportions of felsic layers are very localized and strongly deformed within homogeneous undeformed tonalite (Fig. 3c). Felsic layers might be described as magmatic flow structures surrounding numerous enclaves or blocks of gabbros, hornblendites and ultramafics. The transitional contact between tonalite and the Chelan Igneous Unit indicates that the injection of felsic magmas is concomitant to, or follows

\footnotetext{
$\overline{1}$ Hopson and Mattinson (1994) described this unit as: Heterogeneous mixture of dark-, medium- and light colored metaplutonic and plutonic rocks. Unfortunately they used the term migmatite to name this unit. Although this term is in textural agreement with the observations, it reduces the formation processes of this unit to partial melting following the definition of migmatite by Sawyer (2008). However, this unit could not be formed by in situ partial melting, as already stated by Hopson and Mattinson (1994) who use the term retrograde migmatite (Mehnert 1968) (i.e., leucosomes are the residual product of crystal fractionation). The term of migmatite unit is thus replaced by Chelan Igneous Unit.
}

the emplacement of tonalite (Fig. 3c). These observations imply that most of the deformation took place in the presence of a melt phase.

The melanocratic layers vary in composition from hornblendite to gabbro and are composed of coarse grained green amphibole, plagioclase, epidote, biotite, titanite, ilmenite and quartz (e-table 1). Rutile and apatite are present as accessory minerals. Amphibole is subhedral and aligned in the foliation plane and may contain numerous quartz inclusions. Sphene is often surrounding ilmenite. Plagioclase is unzoned. Vermicular epidote is present at the border of amphibole; however, epidote with allanite-rich cores is also preserved in the melanocratic layers. Epidote is euhedral in contact with biotite and vermicular in contact with quartz and plagioclase indicating a magmatic origin (Zen and Hammarstrom 1984, 1986; Zen 1985). Leucocratic layers vary from tonalites to trondhjemites. They are composed of plagioclase, quartz, biotite and amphibole (e-table 1).

\section{Whole rock chemistry}

\section{Major element chemistry}

All XRF analyses recalculated on an anhydrous basis are reported in Table 1 . The $\mathrm{FeO}_{\text {tot }} / \mathrm{MgO}$ ratio increases with increasing $\mathrm{SiO}_{2}$ and plot in the calc-alkaline field or at the border between the calc-alkaline and tholeiitic field defined by Miyashiro (1974) (Fig. 4a). Using the classification of Cox (1979), the rocks of the Chelan Complex belong to the subalkalic suite and range from gabbros to granite (Fig. 4b). The $\mathrm{Mg}^{\sharp}$ (molar $\mathrm{Mg} /(\mathrm{Mg}+\mathrm{Fe}$ ) considering all $\mathrm{Fe}$ as $\mathrm{FeO}$ ) decreases constantly with increase in $\mathrm{SiO}_{2}$ from 0.84 in the olivine websterite $(\sim 45 \mathrm{wt} \%$ $\left.\mathrm{SiO}_{2}\right)$ to 0.3 in the most differentiated rocks $(\sim 70 \mathrm{wt} \%$ $\mathrm{SiO}_{2}$ ) (Fig. 4). The $\mathrm{Al}_{2} \mathrm{O}_{3}$ content strongly increases at low $\mathrm{SiO}_{2}$ content, before reaching a plateau around 20 $\mathrm{wt} \%$ at about $55 \mathrm{wt} \% \mathrm{SiO}_{2}$ indicating early fractionation of $\mathrm{Al}_{2} \mathrm{O}_{3}$ poor phases such as olivine and pyroxenes. Tonalite and granodiorite (open circle) show a weak decrease in $\mathrm{Al}_{2} \mathrm{O}_{3}$ corresponding to saturation and fractionation of plagioclase. Deformed tonalites (crossed circle) have a lower $\mathrm{Al}_{2} \mathrm{O}_{3}$ and higher $\mathrm{FeO}_{\text {tot }}$ at similar $\mathrm{SiO}_{2}$ compared to undeformed tonalites. While the $\mathrm{Al}_{2} \mathrm{O}_{3}$ shows a sharp break, the $\mathrm{CaO}$ and $\mathrm{FeO}_{\text {tot }}$ content decreases constantly with increasing $\mathrm{SiO}_{2}$. Total alkalies strongly increases with differentiation (up to $7 \mathrm{wt} \%$ ) (Fig. 4b). $\mathrm{K}_{2} \mathrm{O}$ alone displays a more scattered distribution; however, a general trend can be observed. It first increases up to 2.5 wt $\%$ at $55 \mathrm{wt} \%$ of $\mathrm{SiO}_{2}$ and gently decreases for the most differentiated members emphasizing the role of a fractionating K-rich phase (biotite) controlling intermediate to 
Table 1 Bulk rock major element compositions in wt\% of the Chelan Complex determined X-ray fluorescence analysis

\begin{tabular}{|c|c|c|c|c|c|c|c|c|c|c|c|c|c|c|c|c|}
\hline Sample & Rock type & $\mathrm{SiO}_{2}$ & $\mathrm{TiO}_{2}$ & $\mathrm{Al}_{2} \mathrm{O}_{3}$ & $\mathrm{FeO}_{\mathrm{Tot}}{ }^{\mathrm{a}}$ & $\mathrm{MnO}$ & $\mathrm{MgO}$ & $\mathrm{CaO}$ & $\mathrm{Na}_{2} \mathrm{O}$ & $\mathrm{K}_{2} \mathrm{O}$ & $\mathrm{P}_{2} \mathrm{O}_{5}$ & $\mathrm{Cr}_{2} \mathrm{O}_{3}$ & $\mathrm{NiO}$ & $\mathrm{Mg}^{\sharp \mathrm{b}}$ & $\mathrm{ASI}^{\mathrm{c}}$ & LOI \\
\hline C786 & Re-UM & 53.32 & 0.22 & 3.72 & 13.44 & 0.17 & 27.72 & 2.10 & 0.00 & 0.03 & 0.02 & 0.48 & 0.13 & 0.79 & 0.97 & 5.33 \\
\hline C720 & Re-UM & 52.92 & 0.30 & 6.98 & 10.72 & 0.19 & 17.97 & 11.25 & 0.40 & 0.21 & 0.01 & 0.09 & 0.03 & 0.75 & 0.33 & 3.64 \\
\hline CH-7 & Ol-Web & 45.39 & 0.20 & 3.06 & 14.44 & 0.18 & 27.94 & 9.60 & 0.30 & 0.06 & 0.02 & 0.15 & 0.10 & 0.78 & 0.17 & 2.88 \\
\hline CH-9 & Ol-Web & 48.22 & 0.22 & 3.79 & 12.59 & 0.18 & 25.96 & 9.92 & 0.09 & 0.08 & 0.01 & 0.14 & 0.07 & 0.79 & 0.21 & 1.46 \\
\hline C807 & Ol-Web & 47.42 & 0.17 & 3.11 & 13.49 & 0.19 & 28.76 & 7.96 & 0.00 & 0.07 & 0.01 & 0.11 & 0.07 & 0.79 & 0.21 & 2.60 \\
\hline C806 & Px & 51.30 & 0.70 & 5.48 & 14.35 & 0.22 & 19.08 & 9.28 & 0.41 & 0.17 & 0.04 & 0.32 & 0.07 & 0.70 & 0.31 & 2.96 \\
\hline C733 & $\mathrm{Hbl}$ & 46.73 & 0.99 & 8.81 & 11.35 & 0.17 & 15.41 & 16.15 & 0.94 & 0.45 & 0.04 & 0.08 & 0.02 & 0.71 & 0.28 & 1.70 \\
\hline C756 & $\mathrm{Hbl}$ & 43.07 & 1.80 & 14.36 & 13.40 & 0.19 & 14.06 & 11.83 & 1.40 & 1.11 & 0.07 & 0.03 & 0.03 & 0.65 & 0.57 & 1.69 \\
\hline C758 & $\mathrm{Hbl}$ & 45.10 & 1.74 & 12.97 & 14.55 & 0.28 & 13.07 & 9.99 & 1.19 & 2.45 & 0.06 & 0.04 & 0.02 & 0.62 & 0.57 & 1.38 \\
\hline C778 & $\mathrm{Hbl}$ & 47.38 & 0.75 & 7.67 & 20.42 & 0.47 & 15.03 & 9.08 & 0.52 & 0.24 & 0.27 & 0.20 & 0.04 & 0.57 & 0.44 & 1.86 \\
\hline CH-12 & $\mathrm{Hbl}$ & 44.10 & 1.70 & 14.87 & 12.41 & 0.15 & 12.53 & 12.63 & 1.81 & 0.92 & 0.06 & 0.03 & 0.02 & 0.64 & 0.55 & 1.54 \\
\hline CH-8 & $\mathrm{Hbl}$ & 40.00 & 1.95 & 14.85 & 19.36 & 0.15 & 11.58 & 11.55 & 1.75 & 0.70 & 0.04 & 0.01 & 0.00 & 0.52 & 0.60 & 1.25 \\
\hline CNG-1 & Cpx-Ga & 50.74 & 1.06 & 10.42 & 9.25 & 0.16 & 11.39 & 15.44 & 1.63 & 0.48 & 0.19 & 0.15 & 0.02 & 0.69 & 0.33 & 0.70 \\
\hline C734A & Cpx-Ga & 48.42 & 1.49 & 11.36 & 10.86 & 0.23 & 9.87 & 15.89 & 1.89 & 0.63 & 0.34 & 0.10 & 0.01 & 0.62 & 0.35 & 3.44 \\
\hline C704 & Hbl-Ga & 47.41 & 1.95 & 18.99 & 9.94 & 0.12 & 7.63 & 10.46 & 2.86 & 1.41 & 0.22 & 0.00 & 0.00 & 0.58 & 0.75 & 1.22 \\
\hline C775B & Hbl-Ga & 49.78 & 1.02 & 14.44 & 11.33 & 0.19 & 10.02 & 11.10 & 2.49 & 0.44 & 0.17 & 0.14 & 0.02 & 0.61 & 0.58 & 1.49 \\
\hline CHG-5 & Hbl-Ga & 45.50 & 2.07 & 19.07 & 10.42 & 0.10 & 9.17 & 11.41 & 2.59 & 0.64 & 0.05 & 0.01 & 0.01 & 0.61 & 0.74 & 1.91 \\
\hline CHG-3 & Dio & 56.04 & 0.93 & 19.71 & 7.81 & 0.11 & 3.35 & 6.51 & 4.72 & 1.34 & 0.26 & 0.00 & 0.00 & 0.43 & 0.94 & 0.89 \\
\hline CHG-9 & Dio & 53.34 & 0.91 & 20.15 & 8.34 & 0.12 & 3.62 & 8.05 & 4.68 & 1.31 & 0.33 & 0.00 & 0.00 & 0.44 & 0.85 & 0.78 \\
\hline C703 & Dio & 56.05 & 0.82 & 18.30 & 8.19 & 0.12 & 4.36 & 7.67 & 3.90 & 1.15 & 0.24 & 0.01 & 0.01 & 0.49 & 0.85 & 0.96 \\
\hline C706 & Dio & 57.26 & 1.16 & 19.08 & 7.77 & 0.10 & 2.85 & 6.94 & 4.03 & 1.29 & 0.31 & 0.00 & 0.00 & 0.40 & 0.92 & 0.56 \\
\hline C708 & Dio & 59.74 & 0.82 & 17.55 & 6.57 & 0.13 & 3.48 & 6.10 & 4.51 & 1.41 & 0.34 & 0.00 & 0.00 & 0.49 & 0.88 & 0.60 \\
\hline C742 & Dio & 55.80 & 1.28 & 19.40 & & 0.09 & 3.09 & 6.09 & 3.90 & 2.21 & 0.45 & 0.00 & 0.00 & 0.39 & 0.98 & 2.10 \\
\hline C748 & Dio & 59.02 & 1.25 & 18.37 & 7.09 & 0.09 & 2.14 & 5.42 & 4.64 & 2.24 & 0.45 & 0.00 & 0.00 & 0.35 & 0.92 & 0.52 \\
\hline CMD-2 & Dio & 53.86 & 1.07 & 19.62 & 8.35 & 0.15 & 3.51 & 7.74 & 4.58 & 1.62 & 0.34 & 0.00 & 0.00 & 0.43 & 0.84 & 0.69 \\
\hline C724 & Hbl-To & 69.02 & 0.32 & 17.51 & 2.67 & 0.03 & 0.47 & 4.44 & 5.48 & 0.25 & 0.07 & 0.00 & 0.00 & 0.24 & 1.01 & 0.22 \\
\hline C728 & Hbl-To & 65.91 & 0.36 & 18.92 & 3.18 & 0.04 & 0.64 & 4.96 & 5.83 & 0.36 & 0.12 & 0.00 & 0.00 & 0.26 & 1.00 & 0.40 \\
\hline C741 & Hbl-To & 63.88 & 0.47 & 17.90 & 5.23 & 0.14 & 1.38 & 6.07 & 4.89 & 0.36 & 0.21 & 0.00 & 0.00 & 0.32 & 0.92 & 0.49 \\
\hline CT-9 & Hbl-To & 62.82 & 0.45 & 18.61 & 5.24 & 0.12 & 1.73 & 5.78 & 4.76 & 0.82 & 0.20 & 0.00 & 0.00 & 0.37 & 0.97 & 0.78 \\
\hline CT-8 & Hbl-To & 59.64 & 0.71 & 18.38 & 6.19 & 0.09 & 2.93 & 6.50 & 4.53 & 1.42 & 0.23 & 0.00 & 0.00 & 0.46 & 0.88 & 0.43 \\
\hline C710 & Hbl-To & 65.13 & 0.36 & 19.13 & 3.11 & 0.05 & 0.69 & 4.98 & 6.22 & 0.50 & 0.14 & 0.00 & 0.00 & 0.28 & 0.97 & 0.21 \\
\hline C705 & To & 66.95 & 0.31 & 18.66 & 2.75 & 0.02 & 0.62 & 4.63 & 5.66 & 0.55 & 0.12 & 0.00 & 0.00 & 0.29 & 1.02 & 0.47 \\
\hline C712 & To & 65.69 & 0.41 & 19.02 & 3.15 & 0.04 & 0.67 & 4.72 & 5.82 & 0.64 & 0.14 & 0.00 & 0.00 & 0.28 & 1.01 & 0.52 \\
\hline C719 & To & 69.05 & 0.28 & 17.60 & 2.45 & 0.02 & 0.88 & 4.42 & 5.14 & 0.33 & 0.08 & 0.00 & 0.00 & 0.39 & 1.04 & 0.75 \\
\hline C744 & To & 70.84 & 0.23 & 17.05 & 1.85 & 0.02 & 0.53 & 3.54 & 5.47 & 0.59 & 0.06 & 0.00 & 0.00 & 0.34 & 1.06 & 1.26 \\
\hline C746 & To & 68.01 & 0.29 & 18.37 & 2.29 & 0.04 & 0.47 & 4.10 & 5.98 & 0.60 & 0.09 & 0.00 & 0.00 & 0.27 & 1.02 & 0.48 \\
\hline C740 & To & 74.36 & 0.06 & 15.86 & 0.59 & 0.01 & 0.15 & 4.09 & 4.60 & 0.30 & 0.04 & 0.00 & 0.00 & 0.31 & 1.03 & 0.24 \\
\hline C759 & To & 74.28 & 0.18 & 14.44 & 1.40 & 0.03 & 0.28 & 1.70 & 3.57 & 4.20 & 0.05 & 0.00 & 0.00 & 0.26 & 1.07 & 0.49 \\
\hline CT-4 & To & 68.80 & 0.33 & 17.64 & 2.73 & 0.03 & 0.64 & 3.97 & 5.34 & 0.67 & 0.12 & 0.00 & 0.00 & 0.29 & 1.05 & 0.42 \\
\hline CT-10 & To & 73.03 & 0.26 & 15.23 & 1.89 & 0.03 & 0.64 & 2.84 & 5.32 & 0.91 & 0.04 & 0.00 & 0.00 & 0.38 & 1.02 & 0.39 \\
\hline CT-5 & To & 74.58 & 0.12 & 14.35 & 1.13 & 0.04 & 0.22 & 1.73 & 4.08 & 3.82 & 0.04 & 0.00 & 0.00 & 0.26 & 1.03 & 0.21 \\
\hline C749 & To & 70.45 & 0.44 & 15.82 & 2.82 & 0.03 & 0.76 & 3.38 & 3.79 & 2.64 & 0.16 & 0.00 & 0.00 & 0.32 & 1.04 & 0.31 \\
\hline C757 & To & 65.96 & 0.48 & 17.62 & 4.74 & 0.09 & 1.28 & 4.48 & 3.91 & 1.68 & 0.24 & 0.00 & 0.00 & 0.32 & 1.07 & 0.80 \\
\hline $\mathrm{C} 725$ & To & 66.35 & 0.32 & 19.00 & 2.82 & 0.04 & 0.64 & 4.73 & 5.75 & 0.51 & 0.11 & 0.00 & 0.00 & 0.29 & 1.02 & 0.29 \\
\hline C732 & Def-To & 55.85 & 1.00 & 16.77 & 10.81 & 0.20 & 3.72 & 6.66 & 4.32 & 1.57 & 0.17 & 0.01 & 0.00 & 0.38 & 0.80 & 0.78 \\
\hline C721 & Def-To & 64.40 & 0.60 & 14.12 & 8.88 & 0.36 & 2.86 & 5.71 & 3.39 & 0.43 & 0.14 & 0.00 & 0.00 & 0.36 & 0.86 & 1.52 \\
\hline
\end{tabular}


Table 1 continued

\begin{tabular}{lllllllllllllllll}
\hline Sample & Rock type & $\mathrm{SiO}_{2}$ & $\mathrm{TiO}_{2}$ & $\mathrm{Al}_{2} \mathrm{O}_{3}$ & $\mathrm{FeO}_{\mathrm{Tot}}^{\mathrm{a}}$ & $\mathrm{MnO}$ & $\mathrm{MgO}$ & $\mathrm{CaO}$ & $\mathrm{Na}_{2} \mathrm{O}$ & $\mathrm{K}_{2} \mathrm{O}$ & $\mathrm{P}_{2} \mathrm{O}_{5}$ & $\mathrm{Cr}_{2} \mathrm{O}_{3}$ & $\mathrm{NiO}^{\mathrm{N}}$ & $\mathrm{Mg}^{\sharp \mathrm{b}}$ & $\mathrm{ASI}^{\mathrm{c}}$ & $\mathrm{LOI}^{\mathrm{C}}$ \\
\hline $\mathrm{C} 794$ & Def-To & 60.83 & 0.46 & 17.22 & 6.31 & 0.17 & 3.32 & 6.34 & 4.78 & 0.99 & 0.18 & 0.02 & 0.01 & 0.48 & 0.84 & 1.03
\end{tabular}

All data are recalculated on an anhydrous basis

$\mathrm{Re}$-UM retrogressed ultramafic, $\mathrm{Ol}$-web olivine websterite, $\mathrm{Px}$ pyroxenite, $\mathrm{Hbl}$ hornblendite, $\mathrm{Cpx}$ - $\mathrm{Ga}$ clinopyroxene bearing gabbro, $\mathrm{Hbl}$ - $\mathrm{Ga}$ Hornblende gabbro, Dio diorite, $\mathrm{Hbl}$-To Hornblende bearing tonalite, To tonalite/granitoid, Def-To Deformed tonalite, La lamprophyre

${ }^{a}$ All $\mathrm{Fe}$ as $\mathrm{FeO}$

b $\mathrm{Mg}^{\sharp}$ as $\mathrm{Mg} /(\mathrm{Mg}+\mathrm{Fe})$

c ASI as $\left.\mathrm{Al}_{2} \mathrm{O}_{3} / \mathrm{CaO}+\mathrm{Na}_{2} \mathrm{O}+\mathrm{K}_{2} \mathrm{O}\right)$

Fig. 4 Variation diagrams of major elements versus $\mathrm{SiO}_{2}$ content (in wt\%). All FeO is considered as $\mathrm{FeO}_{\text {tot }}, \mathrm{Mg}^{\sharp}=$ molar $\mathrm{Mg} /(\mathrm{Mg}+\mathrm{Fe})$, and ASI corresponds to the aluminum saturation index ASI $=$ molar $\left(\mathrm{Al}_{2} \mathrm{O}_{3} / \mathrm{CaO}+\mathrm{Na}_{2} \mathrm{O}+\mathrm{K}_{2} \mathrm{O}\right)$. Symbols are described in the legend

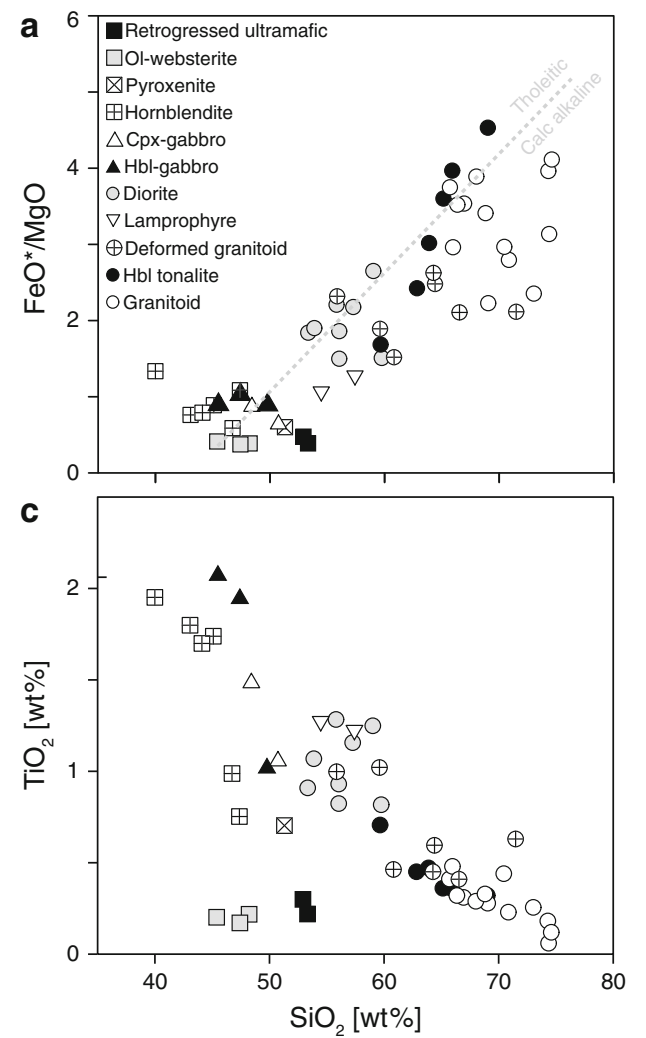

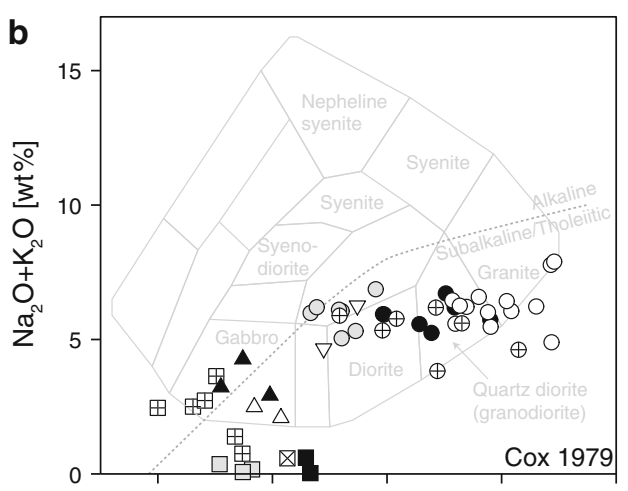

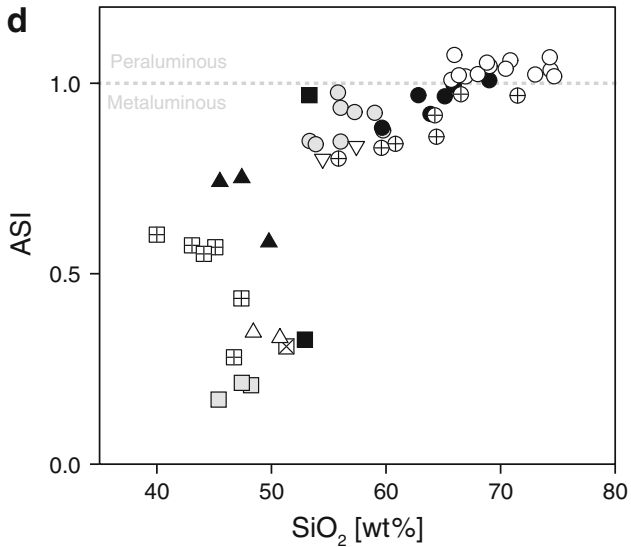

evolved compositions. Pyroxenites and websterites are depleted in $\mathrm{TiO}_{2}(\sim 0.3 \mathrm{wt} \%)$ compared to other rock types (Fig. 4c). Hornblendites display the highest $\mathrm{TiO}_{2}$ concentrations $(\sim 2.0 \mathrm{wt} \%)$ attributed to amphibole accumulation. In hbl gabbros and tonalite, $\mathrm{TiO}_{2}$ decreases constantly at high $\mathrm{SiO}_{2}$ (low $\mathrm{Mg}^{\sharp}$ ). The observed decrease indicates that a Ti-phase (ru, ilm, sph) or Ti-rich amphibole is controlling the bulk $\mathrm{TiO}_{2}$ content. The Al Saturation Index $\left(\mathrm{ASI}=\mathrm{Al}_{2} \mathrm{O}_{3} /\left(\mathrm{CaO}+\mathrm{Na}_{2} \mathrm{O}+\mathrm{K}_{2} \mathrm{O}\right)\right.$ molar units (Zen 1986)) (Fig. 4d) for the Chelan Complex shows two different groups with ultramafics, hornblendites and gabbros plotting in the metaluminous field (ASI $<1$ ), whereas the tonalites straddle the peraluminous (ASI $>1$ ), metaluminous boundary becoming increasingly peraluminous with increasing silica content.
Trace and rare earth element chemistry

Trace element and REE are reported in (Table 2). The trace element patterns exhibit typical features of subduction-related magmatism such as negative anomalies in high field strength element $(\mathrm{Zr}, \mathrm{Nb}, \mathrm{Ta})$ and enrichment in LILE such as $\mathrm{Ba}, \mathrm{Pb}$ and $\mathrm{K}$ (e-fig. 1). The ultramafic rocks display flat REE pattern with a weak positive $(\mathrm{La} / \mathrm{Yb})_{N}$ (e-fig. 2). Hornblendites are enriched in MREE compared to LREE and HREE with $(\mathrm{La} / \mathrm{Sm})_{N}$ ranging from 0.43 to 0.73 and $(\mathrm{Gd} / \mathrm{Yb})_{N}$ around 2 , consistent with hornblende accumulation (e-fig. 2). Gabbros and diorites are enriched in incompatible elements with a $(\mathrm{La} / \mathrm{Yb})_{N}$ of 5-10. However, two gabbros are depleted in LREE relative to MREE suggesting some hornblende accumulation. 


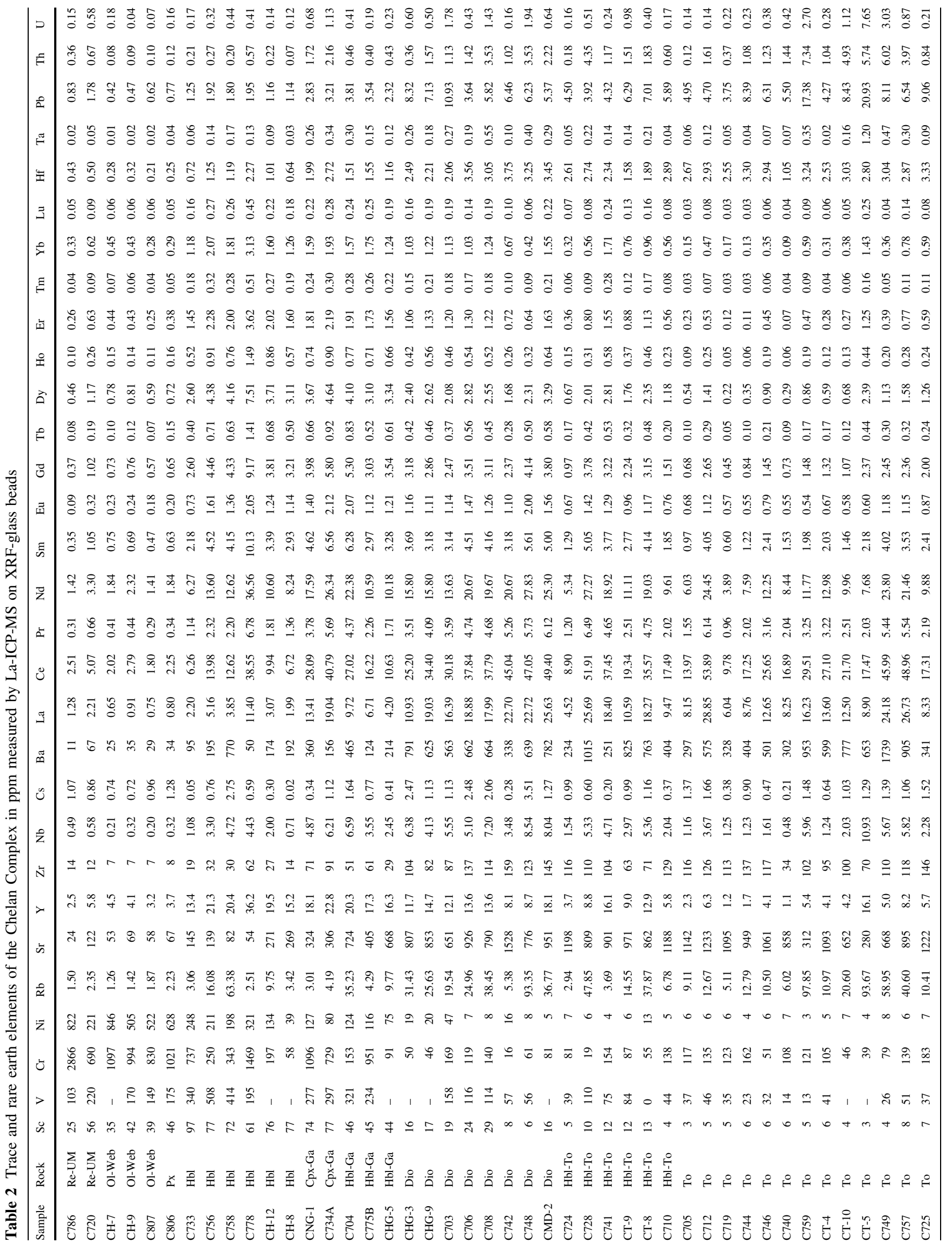




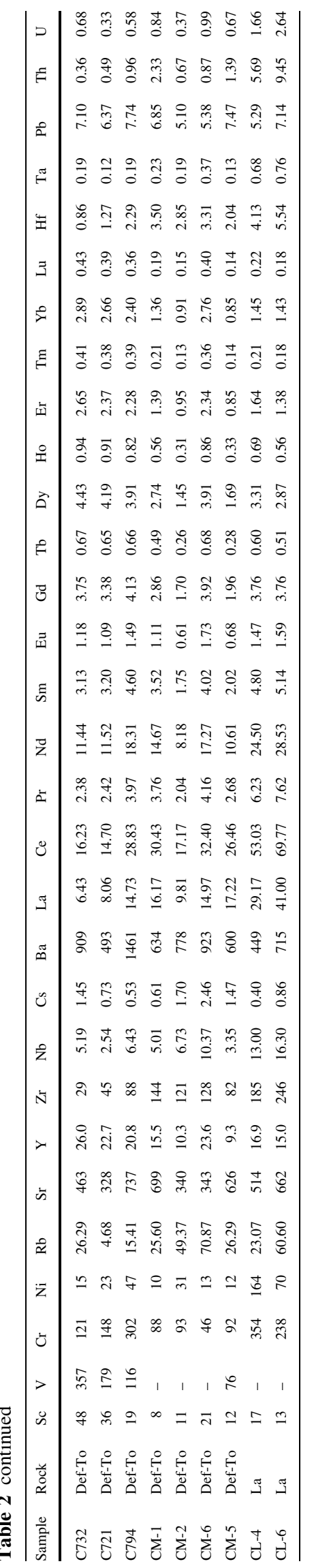

Tonalites are depleted in HREE compared to LREE with a $(\mathrm{La} / \mathrm{Yb})_{N}$ ratio of 7-62. Some tonalites have a spoon shape pattern with a plateau or slight increase in HREE compared to the MREE (e-fig. 2). Such pattern could be related to the fractionation of hornblende which incorporates preferentially MREE compared to HREE. The patterns of deformed granitoids are very similar to the pattern measured for gabbros or tonalites. Two samples of this group have a flat REE pattern that could be the result of mixing between tonalite and ultramafic rocks. The Eu anomaly $\left(\mathrm{Eu}_{N} / \sqrt{\mathrm{Sm}_{N} * \mathrm{Gd}_{N}}\right)$ is poorly developed in the Chelan Complex, and only a few samples display a minor negative or positive anomaly (Fig. 5, (e-fig. 2)) ranging from 0.64 to 3.72 . For the most primitive samples (ultramafics, hornblendites, gabbros and diorites), the lack of negative Eu* excludes early removal of plagioclase. Some tonalites showing a distinct positive Eu anomaly (2.3-3.7) indicating plagioclase accumulation (Fig. 5a).

The $\mathrm{Ni}$ and $\mathrm{Cr}$ (not shown) contents are negatively correlated with $\mathrm{SiO}_{2}$ and strongly decrease with differentiation, from 800 to $1,500 \mathrm{ppm}$ in ultramafic cumulates to values approaching $\sim 5 \mathrm{ppm}$ in tonalites (Fig. $5 \mathrm{~b}$ ). The trends are concordant with early olivine and/or pyroxene fractionation. The chondrite normalized $\mathrm{Dy} / \mathrm{Yb}$ ratio remains constant or slightly decreases with differentiation (Fig. 5c). One diorite contains significant amounts of allanite included in epidote, which drives the $\mathrm{Dy} / \mathrm{Yb}$ ratio to higher $(>3)$ values. HREE and $Y$ decrease with differentiation. Ol-websterite and pyroxenite have very low $Y$ content indicating accumulation of $Y$-poor phases as olivine or pyroxenes. Evaluation of $\mathrm{Sr} / Y$ versus $Y$ relationship reveals that the suite evolves into the adakite field as defined by Defant and Drummond (1990) opposite to the evolution of normal calc-alkaline suites (Fig. 5d). However, the highest $\mathrm{Sr} / \mathrm{Y}$ ratios are coupled with positive $\mathrm{Eu}^{*}$, which is a signature of plagioclase accumulation (Fig. 5d). Thus, the adakitic feature most probably results from a combination of early amphibole fractionation (depleting $Y$ relative to $\mathrm{Sr}$ ) and plagioclase retention further increasing the $\mathrm{Sr}$ content of the bulk rocks.

\section{Mineral chemistry}

All the mineral data are available in electronic appendix for major and trace elements.

\section{Amphibole}

Following the nomenclature of Leake et al. (1997), the amphiboles vary from magnesiohornblende in ultramafic and mafic rocks to ferropargasitic amphibole in tonalites. 
Fig. 5 Whole rock trace and Rare Earth Element variations. Symbols as in (Fig. 4); a Eu anomaly versus $\mathrm{SiO}_{2}$-Absence of anomaly for most but few samples in the Chelan Complex indicates that plagioclase is not involved in the differentiation at early stages. The shaded field represents the absence of an $\mathrm{Eu}$ anomaly $(\mathrm{Eu}$ anomaly $=$ $1 \pm 0.1$; b Evolution of $\mathrm{Ni}$ ppm vs $\mathrm{SiO}_{2}$ wt $\%$. The observed decrease indicates early olivine fractionation; c Constant (Dy/ $\mathrm{Yb})_{N}$ versus $\mathrm{SiO}_{2}$ wt\% is attributed to hornblende fractionation (gray arrow) and excludes early crystallization of garnet (Davidson et al. 2007); d $Y$ versus $\mathrm{Sr} / Y$ of the Chelan Complex evolved through adakite field defined by Defant and Drummond (1990)
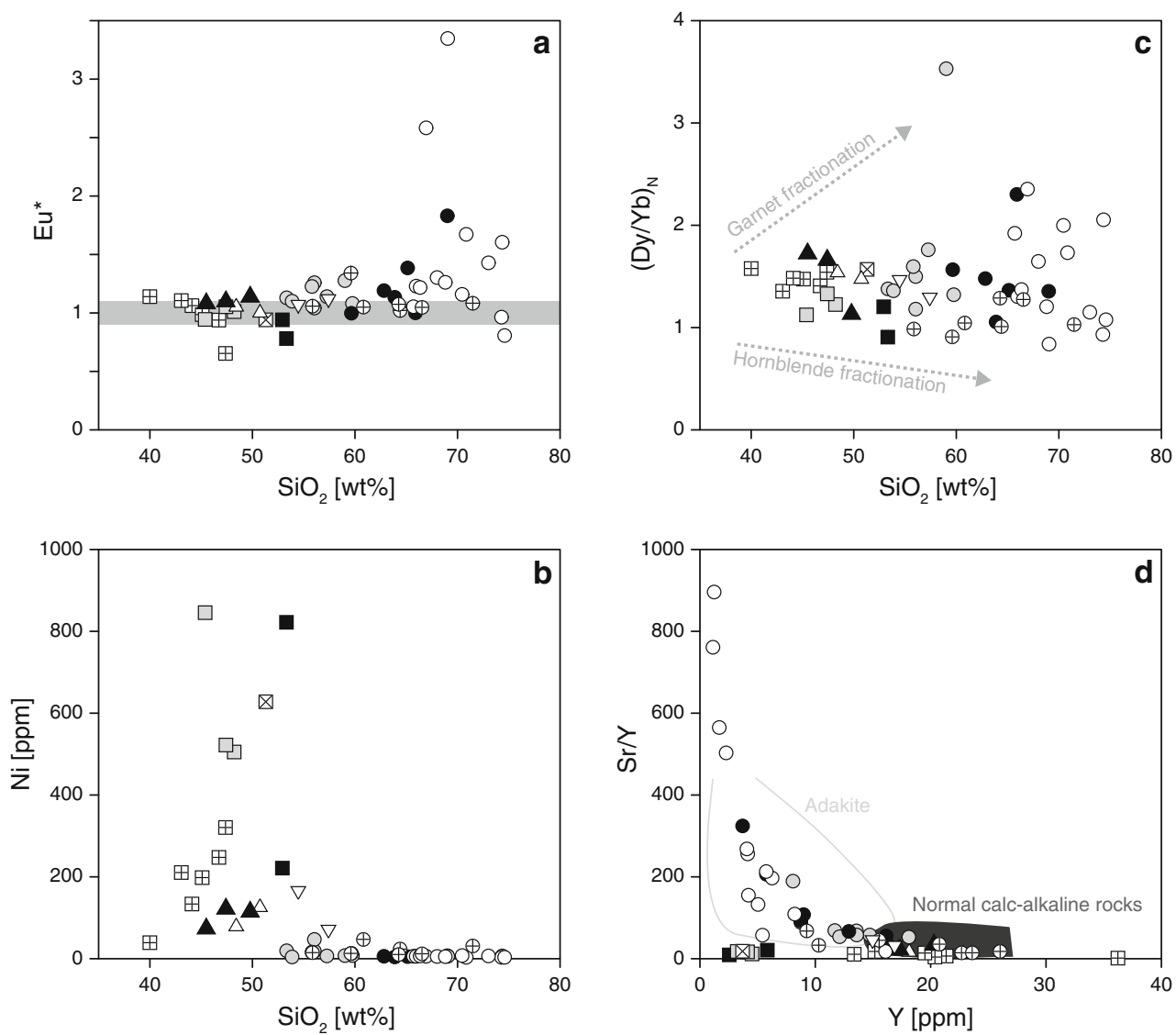

Major element compositions of amphibole display large differences within single sample and show important core to rim variations. The $\mathrm{Mg}^{\sharp}$ (taking all $\mathrm{Fe}$ as $\mathrm{FeO}$ ) increases slightly within sample, whereas the $\mathrm{Al}_{2} \mathrm{O}_{3}, \mathrm{SiO}_{2}$ (Fig. 6a) and $\mathrm{Na}_{2} \mathrm{O}$ show important variations according to the edenite exchange $\left(\mathrm{Na}^{\mathrm{A}} \mathrm{Al}^{\mathrm{IV}} \square_{-1} \mathrm{Si}_{-1}\right)$ (Holland and Blundy 1994) and Tschermak exchange $\mathrm{Al}^{\mathrm{VI}} \mathrm{Al}^{\mathrm{IV}} \mathrm{Mg}_{-1} \mathrm{Si}_{-1}$. They all display a parallel variation in $\mathrm{Na}, \mathrm{Si}$ and $\mathrm{Al}$ p.f.u at different $\mathrm{Mg}^{\sharp}$ (Fig. 6a). Ti p.f.u. is decreasing from core to rim. The variations are more pronounced in ultramafic and mafic rocks than in tonalite where amphibole displays homogeneous compositions (Fig. 6a). The $\mathrm{Mg}^{\sharp}$ decreases from 0.85 in the ol-websterite and pyroxenite to 0.5 in the tonalite (Fig. 6a). The minimum Si p.f.u, which may approach magmatic compositions, is approximately constant at different $\mathrm{Mg}^{\sharp}$ in ultramafic rocks with a value of 6.2. $\mathrm{K}_{2} \mathrm{O}$ increases from $0.6 \mathrm{wt} \%$ in ultramafic rocks to 1.6 wt $\%$ more evolved rocks and is constant between gabbros and tonalites. The $\mathrm{Cr}_{2} \mathrm{O}_{3}$ contents vary widely within sample. In ultramafic rocks, amphibole is enriched in $\mathrm{Cr}_{2} \mathrm{O}_{3}$ reaching a maximum of $1 \mathrm{wt} \%$ in pyroxenite, where amphibole grows at the expense of clinopyroxene. $\mathrm{Cr}_{2} \mathrm{O}_{3}$ decreases with decreasing $\mathrm{Mg}^{\sharp}$ to $0.5 \mathrm{wt} \%$ in gabbros and to $0.2 \mathrm{wt} \%$ in tonalite. Amphibole has a maximum $\mathrm{Ni}$ content of $600 \mathrm{ppm}$ in ultramafic rocks, where amphibole forms rims and reacts with clinopyroxene while the $\mathrm{Ni}$ content of amphibole in gabbros and hornblendite is around $200 \mathrm{ppm}$. Amphibole in tonalite contain less than $50 \mathrm{ppm}$ of Ni. In deformed tonalite, $\mathrm{Ni}$ is slightly higher than in tonalite and diorite at the same $\mathrm{Mg}^{\sharp}$. Yttrium increases with differentiation from $10 \mathrm{ppm}$ in ol-websterite, pyroxenite and hornblendite to $\sim 80 \mathrm{ppm}$ in tonalites (Fig. 6b). Amphiboles in clinopyroxene gabbros display remarkably low $Y$ contents (around $5 \mathrm{ppm}$ ) which could be attributed to equilibrium with titanite incorporating preferentially HREE (Y up to $600 \mathrm{ppm}$ ). One sample with low $\mathrm{Mg}^{\sharp}$ has low $Y(5 \mathrm{ppm})$ (Fig. 6b) and low REE. In this sample, large amounts of euhedral epidote with allanite-rich cores are present depleting coexisting amphibole due to the very high partition coefficients between allanite and amphibole.

The REE patterns of amphiboles display a change from ultramafic to tonalitic bulk rock compositions. In ultramafic rocks, amphibole exhibits a flat REE pattern with only a weak enrichment in MREE compared to LREE and HREE $\left(\mathrm{La}_{N} / \mathrm{Sm}_{N}\right.$ of 0.8 and $\mathrm{Gd}_{N} / \mathrm{Yb}_{N}$ of 1.3 (e-fig. 3)) and a lack of Eu anomaly $(0.85<\mathrm{Eu}<1.16)$. With increasing bulk $\mathrm{SiO}_{2}$, the patterns are shifted to higher chondritic values and MREE becomes progressively enriched compared to LREE and to a lesser extent compared to HREE. The Eu anomaly is still absent or weak in hornblende gabbros and 

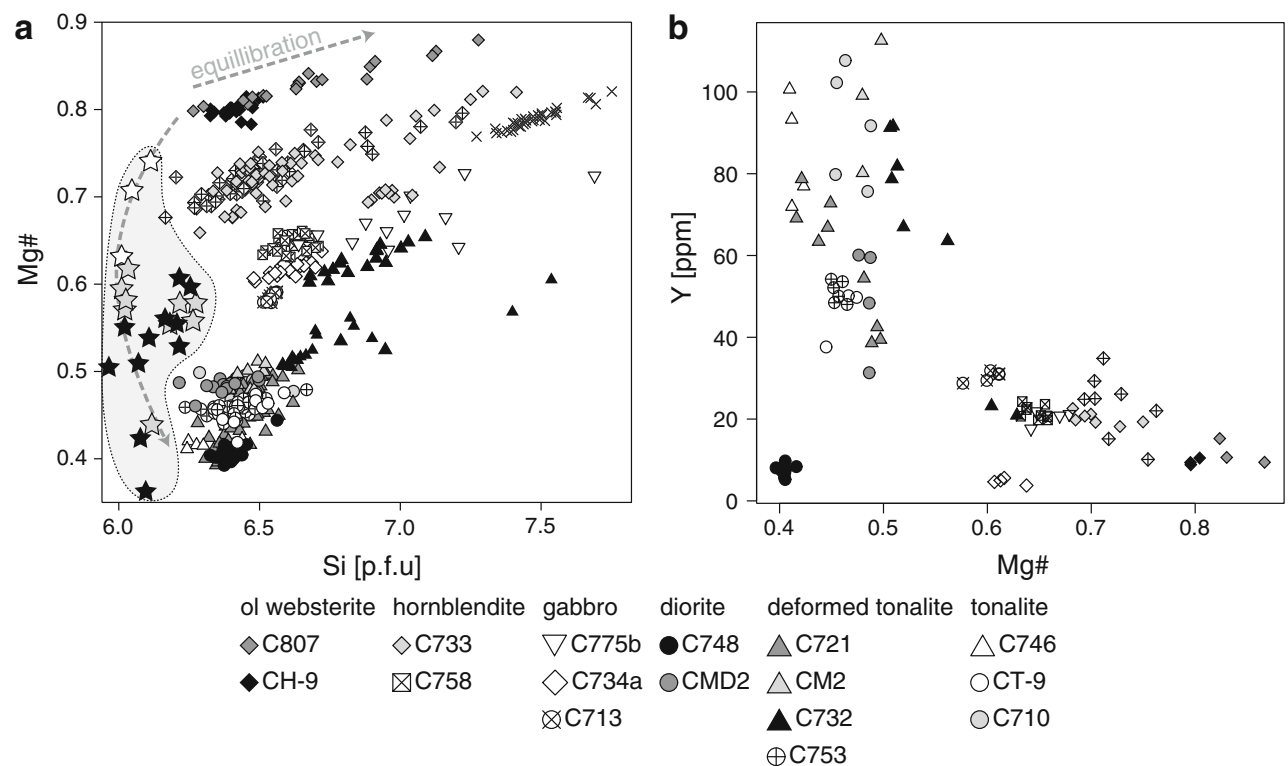

$$
\begin{array}{ll}
\text { pyroxenite } & \text { Experiments } \\
\diamond \mathrm{C} 806 & \lesssim 1.0 \text { [GPa] (Kagi 2000) } \\
\times \mathrm{C} 720 & \lesssim 0.7[\mathrm{GPa}] \text { Low } \mathrm{K} \Delta \mathrm{NNO}=-1 \text { (Sisson et al. 2005) } \\
& \star 0.7 \text { [GPa] Low } \mathrm{K} \Delta \mathrm{NNO}=0 \text { (Sisson et al. 2005) }
\end{array}
$$

Fig. 6 Amphibole chemistry: a Si p.f.u normalized on $15+\mathrm{Na}+\mathrm{K}$ cations after the procedure of Leake et al. (1997) versus $\mathrm{Mg}^{\sharp}$, taking all $\mathrm{FeO}$ as $\mathrm{Fe}^{2+}$. The variations of $\mathrm{Si}$ [p.f.u] at constant $\mathrm{Mg}^{\sharp}$ indicate subsolidus re-equilibration, whereas the decrease in $\mathrm{Mg}^{\sharp}$ indicates magmatic differentiation (see text for discussion). Experimental

diorite and becomes negative in hornblende tonalite $(0.15<\mathrm{Eu}$ anomaly $<0.84)$. The appearance of $\mathrm{Eu}$ anomalies indicates that amphibole in tonalite crystallizes concomitantly or after plagioclase.

\section{Plagioclase}

In ultramafic rocks, plagioclase is interstitial and the composition is almost pure anorthite $\left(\mathrm{An}_{98-100}\right)$. In hornblendite and gabbro, the composition is very homogeneous with most analyses plotting at $\mathrm{X}_{a n} \sim 40 \%$ (e-fig. 4). The lack of zonations suggest cooling or re-equillibration at high temperature. In tonalites, plagioclase composition is similar to gabbros, with some notable exceptions in diorite where the composition varies continuously from core $\left(\mathrm{An}_{60}\right)$ to rim $\left(\mathrm{An}_{30}\right)$ (e-fig 4).

The REE patterns are enriched in LREE compared to the MREE $\left(\mathrm{La}_{N} / \mathrm{Sm}_{N}\right.$ ranging from 4 to 20$)$ and HREE with a large positive Eu anomaly (e-fig 5). In deformed tonalite, one sample has higher LREE content compared to the other. The plagioclase measured in diorite sample $\mathrm{C} 748$ has $\sim 10$ times lower REE content than comparable rocks (efig. 5). The early appearance of epidote and allanite in this sample may be responsible for the low REE abundance in plagioclase. amphibole composition (stars) is taken from (Kägi 2000; Sisson et al. 2005) and the gray field contours the magmatic composition of amphibole; b Variation of $Y$ content as a function of $\mathrm{Mg}^{\sharp}$ in amphibole

\section{Clinopyroxene}

Clinopyroxene is diopside in composition (e-fig. 6). The $\mathrm{Mg}^{\sharp}$ of clinopyroxene is homogeneous within a single sample and decrease from olivine websterite $(0.88-0.91)$ to clinopyroxene bearing gabbros $(0.75-0.78)$ with the noteworthy exception of clinopyoxene in pyroxenite where a zonation is present. In pyroxenite, $\mathrm{Mg}^{\sharp}$ is more variable with high values in the core (0.89) decreasing toward the rim (0.82). At the border, the $\mathrm{Mg}^{\sharp}$ increases again to 0.84 (Fig. 7). $\mathrm{Al}_{2} \mathrm{O}_{3}$ varies widely with a maximum values of $4 \mathrm{wt} \%$ in olivine websterite and pyroxenite and $2 \mathrm{wt} \%$ in clinopyroxene bearing gabbros (Fig. 7). In pyroxenite, where pyroxene is zoned, it displays a different trend with an increase in $\mathrm{Al}_{2} \mathrm{O} 3$ form core to rim. At the border, $\mathrm{Al}_{2} \mathrm{O}_{3}$ decreases to $<2.0 \mathrm{wt} \%$. $\mathrm{Na}_{2} \mathrm{O}$ and $\mathrm{TiO}_{2}$ behave similarly to $\mathrm{Al}_{2} \mathrm{O}_{3}$ indicating coupled substitutions between these elements.

In ultramafic rocks, clinopyroxene contains high $\mathrm{Cr}$ contents (up to 2,500 ppm in pyroxenite and 1,300 ppm in olivine websterite) and $\mathrm{Ni}$ (400 ppm in pyroxenite and $180 \mathrm{ppm}$ in olivine websterite). These values drop to less than $500 \mathrm{ppm}$ of $\mathrm{Cr}$ and $100 \mathrm{ppm}$ of $\mathrm{Ni}$ in hornblendite and clinopyroxene bearing gabbros.

The absence of any Eu anomaly in the REE patterns indicates that pyroxene crystallizes prior to plagioclase (e-fig. 7). 


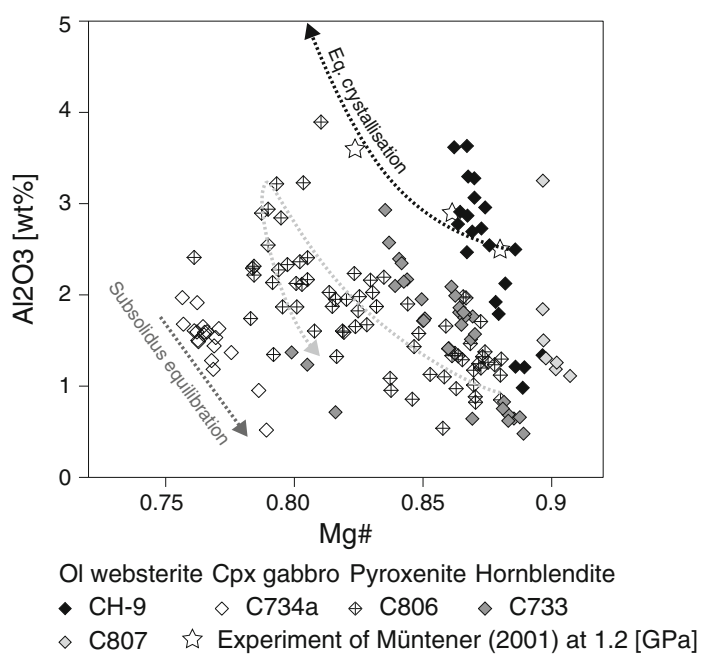

Fig. 7 Variation of $\mathrm{Al}_{2} \mathrm{O}_{3}$ with $\mathrm{Mg}^{\sharp}$ in clinopyroxene. The parallel trends observed in each samples are assigned to the effects of cooling. The change in $\mathrm{Al}_{2} \mathrm{O}_{3}$ is attributed to magmatic differentiation. The lightest gray arrows represent the general zoning observed in sample C806

In general, MREE are slightly enriched compared to LREE and HREE and amount to $1-5$ times chondrite for pyroxenes in olivine websterite and hornblendite. In pyroxenite, the enrichment in MREE is higher than in other ultramafic rocks and exhibits about 10 times chondritic values.

\section{Orthopyroxene}

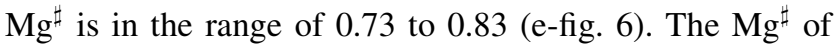
orthopyroxene is lower than that of coexisting clinopyroxene. The variations observed for $\mathrm{Al}_{2} \mathrm{O}_{3}$ are similar to clinopyroxene, albeit at lower absolute concentrations (ranging from 0.6 to $3 \mathrm{wt} \%$ ). $\mathrm{CaO}$ is generally less than $1.0 \mathrm{wt} \%$. Orthopyroxene is depleted in LREE, with a variation of $\left(\mathrm{La}_{N} / \mathrm{Yb}_{N}\right)$ from 0.04 to 0.24 . Some orthopyroxenes have a convex REE pattern. Ni content is higher in pyroxenite than in ol-websterite, suggesting that orthopyroxene replaces olivine, following the peritectic reaction, ol+melt $\rightarrow$ opx. Cr concentration is almost constant at $\sim 750 \mathrm{ppm}$ among the different samples.

\section{Olivine}

Olivine composition is very homogeneous with forsterite contents ranging from 0.79 to 0.82 . The concentration of $\mathrm{Ni}$ and $\mathrm{Cr}$ is high (up to 1,000 ppm for $\mathrm{Ni}$ and $200 \mathrm{ppm}$ for $\mathrm{Cr}$ ).

\section{Epidote}

Epidote is a common mineral in evolved plutonic rocks and may be present locally in clinopyroxene gabbros $(<2 \%)$. Epidote generally displays vermicular intergrowth with quartz and is always associated with an allanite-rich core. Epidote matches the criteria for magmatic origin (Zen and Hammarstrom 1984, 1986; Zen 1985) indicating a pressure of crystallization in excess of $0.6 \mathrm{GPa}$. The compositions are Fe rich with an $\mathrm{X}_{e p}(\mathrm{Fe} /(\mathrm{Fe}+\mathrm{Al}+\mathrm{Cr}-2)$ as molar) ranging from 0.7 to 0.8 . Some cores have compositions containing more than $10 \mathrm{wt} \%$ of LREE, indicating substantial allanite component following the coupled substitution $\mathrm{Ca}_{-1}^{2+}(\mathrm{Al}, \mathrm{Fe})_{-1}^{3+} \mathrm{REE}_{1}^{3+} \mathrm{Fe}_{1}^{2+}$ (Giere and Sorensen 2004).

\section{Biotite}

Biotite is present as an accessory mineral in hornblendites and gabbros and as major phase in tonalites. $\mathrm{The}^{\mathrm{TiO}_{2}}$ content is homogeneous between 2 and $3 \mathrm{wt} \%$ independent of the samples and, hence, bulk composition. $\mathrm{Mg}^{\sharp}$ varies between 0.4 and 0.55 in tonalite and reached 0.65 to 0.70 when present in hornblendites. $\mathrm{Na}_{2} \mathrm{O}$ is slightly enriched in hornblendite $(0.3 \mathrm{wt} \%)$ compared to tonalite $(0.1 \mathrm{wt} \%)$. Recalculated $\mathrm{Al}^{[I V]}$ are lower in hornblendite than in tonalite.

\section{Discussion}

Magmatic history of the Chelan Complex

Numerous magmatic textures are preserved within the complex such as magmatic breccias in ultramafic bodies, mingling textures between tonalites and gabbros, presence of comb layer within tonalite and intrusive contacts between different batches of evolved melts (Figs. 2, 3). Correlations between major elements are coherent with magmatic differentiation, such as a decrease in $\mathrm{Mg}^{\sharp}$ and increase in incompatible elements $\left(\mathrm{Na}_{2} \mathrm{O}\right.$ and $\left.\mathrm{K}_{2} \mathrm{O}\right)$ with increasing $\mathrm{SiO}_{2}$ (Fig. 4), and follow a calc-alkaline differentiation trend (Miyashiro 1974) (Fig. 4a). Trace elements exhibit typical features of subduction-related magmatism such as negative anomalies in high field strength element ( $\mathrm{Zr}, \mathrm{Nb}, \mathrm{Ta})$ and enrichment in LILE such as $\mathrm{Ba}, \mathrm{Pb}$ and $\mathrm{K}$. Field relations and whole rock chemistry indicate that most of the Chelan Complex was formed by magmatic processes in a supra-subduction environment and, thus, provides crucial information toward the understanding of differentiation processes operating above subduction zones in deep to intermediate level crustal magma reservoirs.

\section{Ultramafic cumulates}

Olivine websterite, pyroxenite and hornblendite are the most primitive magmatic rocks exposed in the Chelan 
Complex. Preservation of cumulate textures such as poikilitic hornblende enclosing olivine and pyroxenes, euhedral hornblende surrounded by tiny amounts of interstitial plagioclase clearly indicate that they are igneous cumulates. Olivine websterite are enriched in $\mathrm{Ni}$ (up to $800 \mathrm{ppm}$ ) and $\mathrm{Cr}$ reflecting early olivine crystallization and accumulation. The moderate concentrations of $\mathrm{Al}_{2} \mathrm{O}_{3}$ in pyroxene ( $3 \mathrm{wt} \%$ ) are similar to values measured in pyroxene measured from the Tonsina ultramafic assemblages (DeBari and Coleman 1989) or experimental pyroxene (Kägi 2000; Müntener et al. 2001) from hydrous calc-alkaline magmas (Fig. 7). The low $\mathrm{Al}_{2} \mathrm{O}_{3}$ contents and high $\mathrm{Mg}^{\sharp}$ imply that pyroxene in olivine websterite crystallizes early after olivine saturation. Hornblendite (or hornblende pyroxenite) that is lower in $\mathrm{Mg}^{\sharp}, \mathrm{Ni}$ (Fig. 5b) and $\mathrm{Cr}$ contents crystallize after olivine websterite. Hornblendite preserved heteradcumulate textures (Fig. 2b), with variable proportion of plagioclase as intercumulus phase $(0-10 \%)$. The REE pattern of hornblendite, enriched in MREE compared to LREE and HREE, is similar to hornblende itself (e-fig. 2) indicating an igneous origin by the accumulation of hornblende primocryst. Relics of pyroxenes enclosed in the core of amphibole in some hornblendites reflect the peritectic reaction pyroxene + melt $\rightarrow$ amphibole indicating that pyroxene formed as cumulus and has been replaced by variable amounts of amphibole depending on the availability of interstitial melt. The $\mathrm{Al}_{2} \mathrm{O}_{3}$ content of pyroxene (4 wt\%) reflects the early appearance of amphibole in the system as liquidus phase or as a product of a peritectic reaction. Al will preferentially enter the amphibole lattice and limits the $\mathrm{Al}$ enrichment in pyroxene. Gabbro is intrusive into ultramafic rocks, and the observed decrease in $\mathrm{Mg}^{\sharp}, \mathrm{Cr}$ and $\mathrm{Ni}$ (Fig. 5b) contents from olivine websterite to pyroxenite to hornblendite and finally to gabbro allows to establish the sequence of crystallization within the Chelan Complex as follows: olivine $\rightarrow$ clinopyroxene/ orthopyroxene $\rightarrow$ hornblende $\rightarrow$ plagioclase.

\section{Delay in plagioclase saturation and early amphibole fractionation}

Several observations indicate that plagioclase is not involved in the early evolution of the Chelan Complex. Plagioclase is present only as an occasional intercumulus phase surrounding amphibole in high $\mathrm{Mg}^{\sharp}$ cumulates such as hornblendites and gabbros. The increase in $\mathrm{Al}_{2} \mathrm{O}_{3}$ at low silica content ( $\sim 48 \mathrm{wt} \%)$ (Fig. 4) and enrichment in $\mathrm{Al}_{2} \mathrm{O}_{3}$ of clinopyroxene (Fig. 7) exclude early plagioclase fractionation and shows that $\mathrm{Al}$-poor phases such as olivine, clinopyroxene and orthopyroxene crystallize early. An Eu anomaly is absent or weak in almost all the rocks of the complex, except for some tonalites exhibiting positive $\mathrm{Eu}$ anomalies (Fig. 5a, (e-fig. 2)). Pyroxene and hornblende in ultramafic rocks and gabbros are lacking any appreciable Eu anomaly (e-fig 3), supporting textural observations. The rare occurrence of olivine websterite and pyroxenite compared to hornblendite together with relatively weak enrichment in $\mathrm{Al}_{2} \mathrm{O}_{3}$ in clinopyroxene (Fig. 7) indicates that olivine and pyroxene crystallization are reduced to a short interval before hornblende saturation. Similarly, as amphibole incorporates preferentially MREE compared to HREE (e.g., Tiepolo et al. 2007), the constant Dy/Yb with the increase in $\mathrm{SiO}_{2}$ is interpreted as amphibole signature (Fig. 5c) (Davidson et al. 2007). Amphibole chemistry follows the trend of experimental magmatic amphibole at intermediate pressure (0.7-1.0 GPa) (Kägi 2000; Sisson et al. 2005) at least regarding low $\mathrm{Mg}^{\sharp}$ and low Si p.f.u contents (Fig. 6a). These observations support the central role of amphibole in the evolution of the geochemical signature of the Chelan Complex.

\section{Cooling history of the Chelan Complex}

\section{Subsolidus re-equilibration}

Whereas field relations and whole rock chemistry point out that the principal evolution of the Chelan Complex was controlled by igneous processes, microtextural observations and mineral chemistry record additional subsolidus processes under postemplacement conditions in the granulite-amphibolite facies. In olivine websterite, plagioclase is largely replaced by green spinel and clinopyroxene symplectite, whereas olivine is replaced by orthopyroxene and magnetite symplectite. Exsolution lamellae in clinopyroxenes and orthopyroxenes are common in ol-websterite and pyroxenite and are often interpreted as reflecting slow cooling rates (DeBari and Coleman 1989) that drives clinopyroxene composition to higher and orthopyroxene to lower wollastonite content, due to the widening of the miscibility gap between orthopyroxene and clinopyroxene with decreasing temperature (Lindsley 1983). The increase in $\mathrm{Mg}^{\sharp}$ toward the rim of clinopyroxene together with a decrease in $\mathrm{Al}_{2} \mathrm{O}_{3}$ is interpreted as a metamorphic trend related to cooling (Fig. 7) (Jagoutz et al. 2007). Rare relicts of brown amphibole exhibiting Ti exsolution lamellae that are surrounded by green amphibole indicate changing conditions during amphibole growth. The compositions of amphibole within a single sample display parallel trends with an increase in Si p.f.u and to a lesser extent $\mathrm{Mg}^{\sharp}$ toward the rim, especially in ultramafic and mafic rocks (Fig. 6a). These changes in amphibole composition are temperature dependent and are indicative of cooling (Holland and Blundy 1994). The distribution of $\mathrm{Al}_{2} \mathrm{O}_{3}$ and $\mathrm{TiO}_{2}$ within single grains indicates that the composition 
evolved along $\mathrm{a} \pm$ isobaric cooling path following the semiquantitative thermo-barometer of Ernst and Liu (1998). Similarly, the change in Ti-bearing phases from rutile $\rightarrow$ ilmenite $\rightarrow$ sphene in hornblendite and gabbro documents a metamorphic reaction series due to cooling (Ernst and Liu 1998).

\section{Pressure estimate}

The pressure of emplacement is rather difficult to constrain due to the lack of appropriate mineral assemblages for barometry. However, the mineralogy of cumulates can potentially be utilized to constrain a minimum pressure of emplacement and to quantify the depth where subsolidus reaction occurred. Water-saturated experiments indicate that garnet is stable at pressure exceeding 1.0-1.2 GPa in basaltic and andesitic systems. The absence of garnet in the Chelan Complex, therefore, excludes pressures in excess of $1.2 \mathrm{GPa}$. Likewise, the occurrence of magmatic epidote indicates a minimum pressure of $\sim 0.5-0.6 \mathrm{GPa}$ (see Schmidt and Poli 2004, for a review) for tonalite and gabbro. As the tonalites are intrusive into ultramafic rocks, the emplacement pressure of ultramafic rocks should be similar to that of tonalite. Olivine websterites display the association of $\mathrm{ol}+\mathrm{plg}+\mathrm{cpx}+\mathrm{opx}+\mathrm{sp}$ that has a limited pressure stability of 1.0-1.35 GPa (e.g., Green and Ringwood 1967; Müntener et al. 2000). At lower pressure, olivine and plagioclase are stable instead of orthopyroxene, clinopyroxene and spinel, and at higher pressure, olivine and garnet should be present which is not the case. Using the semiquantitative thermobarometer of Ernst and Liu (1998) based on $\mathrm{Al}_{2} \mathrm{O}_{3}$ and $\mathrm{TiO}_{2}$ distribution in amphibole, the core to rim variation indicates a restricted pressure interval from 1.0 to $0.6 \mathrm{GPa}$. Amphibole in experiments conducted on high $\mathrm{Mg}^{\sharp}$ basalt at different pressures provide a correlation between pressure and $\mathrm{Al}^{[V I]}$ and can be used as an empirical geobarometer (Larocque and Canil 2010). The natural samples display more variations due to subsolidus reactions, the estimated pressures amount to 1.4 GPa to $0.8 \mathrm{GPa}$ in ultramafic, 1.0 to 0.7 in gabbros and around $1.0 \mathrm{GPa}$ in tonalites.

\section{Temperature estimates}

The temperature estimates performed on the different mineralogical assemblages yield a tight range of temperature (Table 3). Two pyroxenes thermometry using the calibration of Wells (1977) and Lindsley (1983) resulted in temperatures around $800^{\circ} \mathrm{C}$ for olivine websterite. However, rare clinopyroxene with low $\mathrm{CaO}(22.5 \mathrm{wt} \%)$ yields higher temperature of $950^{\circ} \mathrm{C}$. In pyroxenite, where relict of magmatic textures are preserved (brown amphiboles,
Table 3 Temperature in ${ }^{\circ} \mathrm{C}$ calculated using different mineral pairs

\begin{tabular}{lllll}
\hline Sample & RockType & Hbl-Plg $^{\mathrm{a}}$ & Allanite $^{\mathrm{b}}$ & Opx Cpx $^{\mathrm{c}}$ \\
\hline C720 & Re-UM & 485 & - & - \\
CH-9 & Ol-Web & - & - & 750 \\
C807 & Ol-Web & - & - & 770 \\
C806 & Px & - & - & $950(\mathrm{r}), 1050(\mathrm{c})^{\mathrm{d}}$ \\
C758 & Hbl & 780 & - & - \\
C734A & Cpx-ga & 793 & - & - \\
C748 & Dio & $850(\mathrm{r}), 950(\mathrm{c})^{\mathrm{d}}$ & 830 & - \\
CMD-2 & Dio & $850(\mathrm{r}), 920(\mathrm{c})^{\mathrm{d}}$ & 790 & - \\
C724 & Hbl-To & 777 & - & - \\
CT-9 & Hbl-To & 797 & - & - \\
C746 & To & 837 & 776 & - \\
C749 & To & - & 830 & - \\
C732 & Def-To & 760 & - & - \\
C721 & Def-To & 797 & - & - \\
CM-2 & Def-To & 814 & - & - \\
\hline
\end{tabular}

a Holland and Blundy (1994)

b Klimm et al. (2008)

c Wells (1977)

d Rim, core

magmatic zonation in ortho and clinopyroxenes), two pyroxene thermometry indicates temperature around $950^{\circ} \mathrm{C}$ for the clinopyroxene rims and higher temperature for the core at around $1050^{\circ} \mathrm{C}$. Due to the presence of exsolution lamellae in both pyroxenes, the calculated temperatures most probably reflect minimum temperatures. Hornblende plagioclase thermometry (Holland and Blundy 1994) assuming a pressure of $1.0 \mathrm{GPa}$ yields similar temperature to the two pyroxene thermometer and ranges from 750 to $850^{\circ} \mathrm{C}$ in gabbros and hornblende bearing tonalite. However, the temperatures obtained in samples containing plagioclase with An-rich cores $\left(\mathrm{An}_{60}\right)$ are $100^{\circ} \mathrm{C}$ higher resulting in a temperature of $950^{\circ} \mathrm{C}$. The allanite saturation thermometer of Klimm et al. (2008) provides temperature of $\sim 800^{\circ} \mathrm{C}$, similar to the hornblende-plagioclase thermometer.

Major element and trace element modeling

\section{Model setup}

In order to test a possible, proposed cogenetic origin of the different rocks forming the Chelan Complex, straight-forward fractional crystallization modeling was performed and the results are compared with the bulk rock analysis. Textural observations and geochemical constraints indicate that ultramafic rocks, gabbros, diorite and some tonalites/ granitoid represent cumulates. The model is based on the step-by-step subtraction of fixed whole rock compositions 


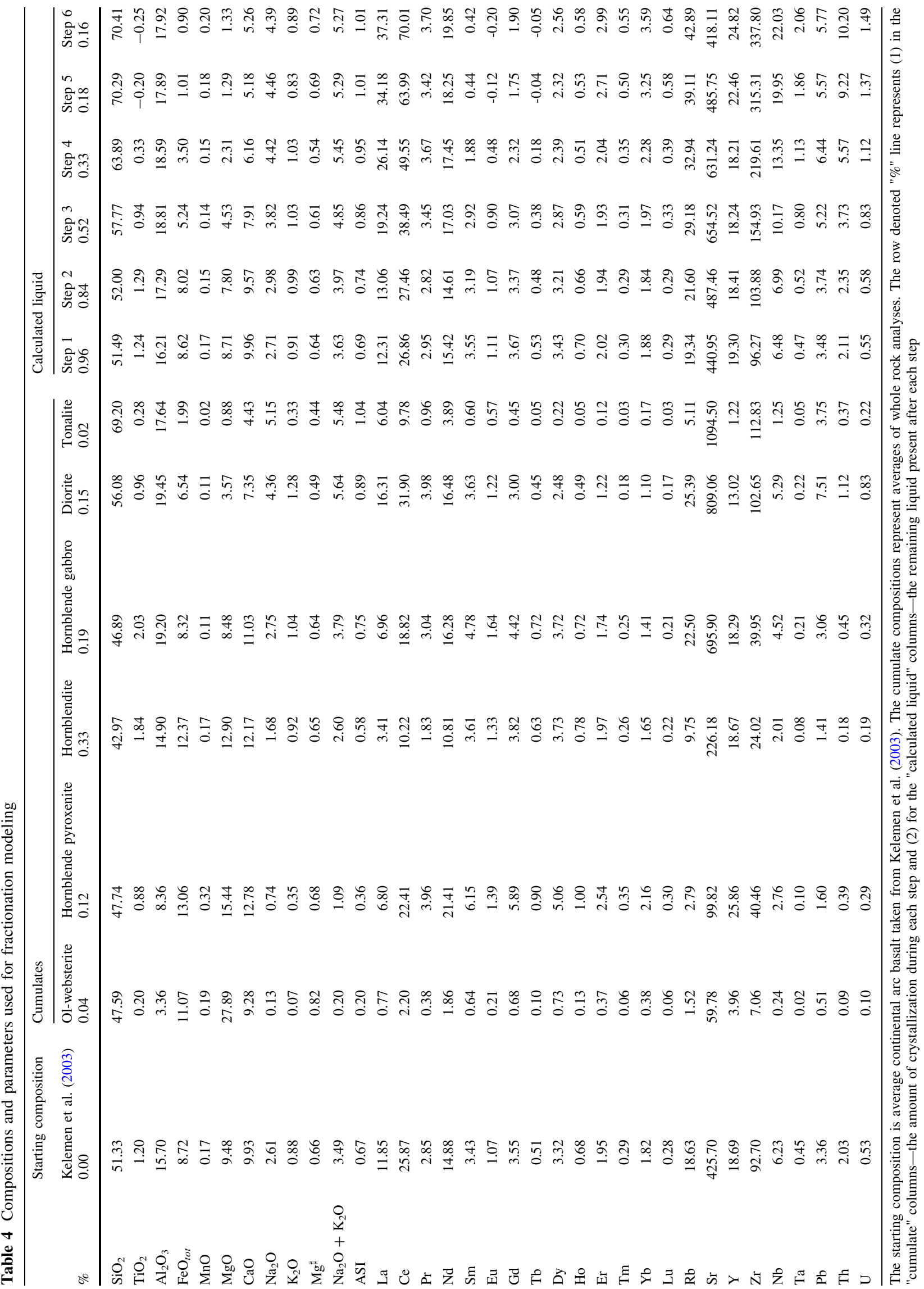


for major and trace element instead of utilizing mineralmelt partition and exchange coefficients and corresponding equations for fractional or equilibrium crystallization. The relationship between parental melt, cumulates and derivative liquid has been mass-balanced according to:

$C_{i}^{\text {liq }}=C_{0_{i}}^{\text {liq }}-f C_{i}^{\text {sol }}$

where $f$ is the fraction of solid removed, $C_{0_{i}}^{\text {liq }}$ is the initial concentration of element $\mathrm{i}$ in the liquid phase, and $C_{i}^{\mathrm{sol}}$ is the concentration of the element $i$ in the solid assemblage removed. Whole rock chemistry was used as $C_{i}^{\text {sol }}$. All cumulates and calculated liquids are normalized to $100 \%$ on an anhydrous basis.

The succession of cumulates is constrained by field relationships and bulk rock chemical arguments. The model is divided into six steps as follow: olivine websterite $\rightarrow$ pyroxene hornblendite $\rightarrow$ hornblendite $\rightarrow$ hornblende gabbro $\rightarrow$ diorite $\rightarrow$ tonalite (Table 4 ). Each fractionating composition is represented by average of the different samples measured in this study for each rock type. In case of significant variations of the $\mathrm{Mg}^{\sharp}$, the most primitive sample within the group was selected. Samples presenting clear evidence of reaction with trapped melt were excluded for modeling. Due to the complex field relations within the Chelan Igneous Unit, characterized by numerous enclaves of hornblendite and gabbros in tonalite, partial lack of outcrops and the unknown volume covered by the Columbia River basalt, it is difficult to properly estimate the volumes of each unit solely on the basis of existing maps and field observations. Therefore, in the model, the volumes of the different units were adjusted to obtain a best fit of the trend described by whole rock analysis, but generally trying to respect relative proportions of different rock types observed in the field. Because no chemical constraints for primitive liquid compositions exist for the Chelan Complex, the average compositions of continental arcs compiled by Kelemen et al. (2003) were taken as starting composition for trace and major element modeling. The composition corresponds approximately to a nearprimary, slightly silica-enriched, calc-alkaline basalt; the validity of this assumption will be discussed later.

\section{Major element evolution}

The trend for major elements is reproduced successfully by the sequence of rocks observed in the field. The best match to the bulk rock analysis is obtained with crystallization of the following volumes: $4 \%$ of olivine websterite, $12 \%$ of pyroxene hornblendite, $33 \%$ of pure hornblendite, $19 \%$ of hornblende gabbros, $15 \%$ of diorite and $2 \%$ of tonalite. After fractionation, $16 \%$ of liquid remains (Table 4 ). The removal of olivine websterite and hornblende pyroxenite increases $\mathrm{Al}_{2} \mathrm{O}_{3}, \mathrm{~K}_{2} \mathrm{O}, \mathrm{TiO}_{2}$ and $\mathrm{Na}_{2} \mathrm{O}$ and results in a decrease in $\mathrm{MgO}$ and $\mathrm{FeO}_{\text {tot }}$ at roughly constant $\mathrm{SiO}_{2}$ (Fig. 8), because olivine websterite and pyroxenite contain similar $\mathrm{SiO}_{2}$ concentrations as the starting material. The critical step in the fractionation sequence is the appearance
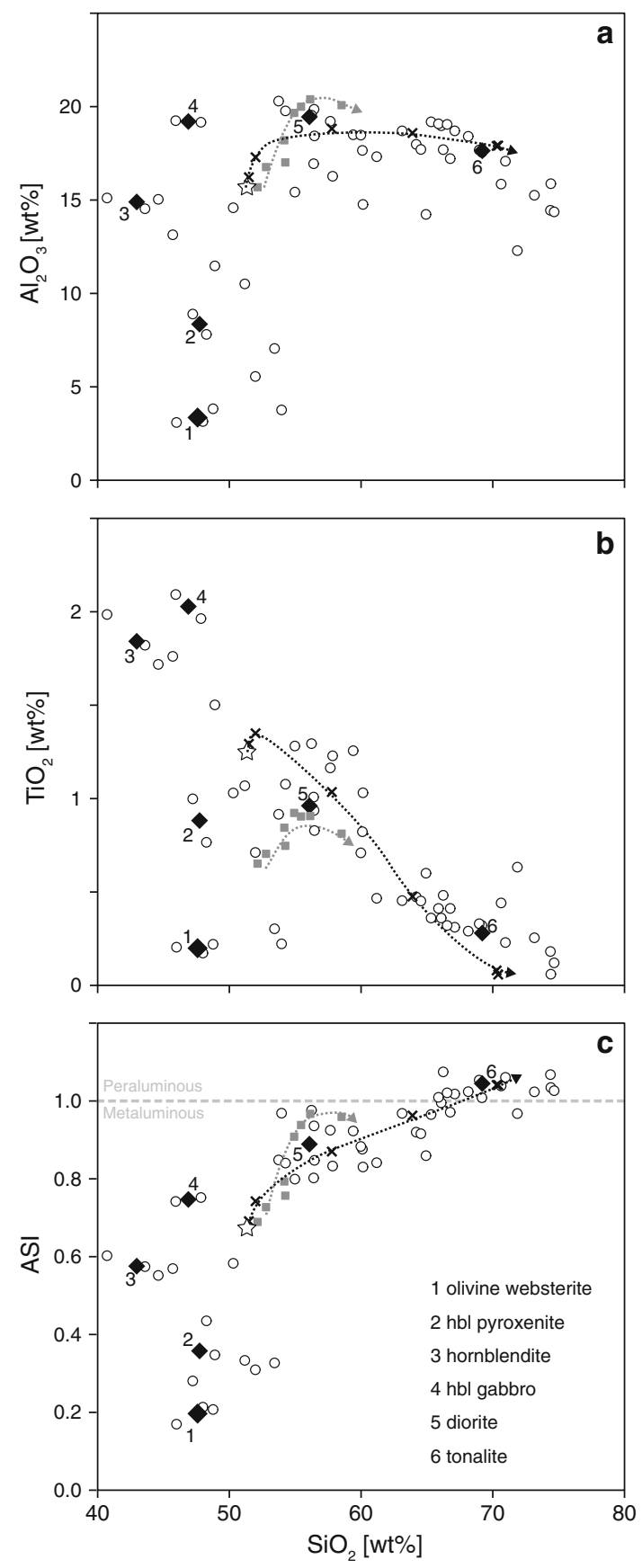

Fig. 8 Comparison of the results of the crystal fractionation modeling (black crosses), whole rock compositions (open circle), and highpressure experiment of Kägi (2000) (gray square) for major elements. Gray diamonds represent the chemistry of cumulates used as cumulate compositions in the modeling. The numbers represent each steps. The liquid used as a starting composition (white star) corresponds to the average continental arc of Kelemen et al. (2003) 
of hornblende-dominated cumulates, which are depleted in $\mathrm{SiO}_{2}$ compared to the calculated, coexisting liquid (40-42 $\mathrm{wt} \%$ in hornblendite compared to $52-53 \mathrm{wt} \%$ in the liquid). Fractionation of hornblendite strongly increases the $\mathrm{SiO}_{2}$ content in the liquid up to $57 \mathrm{wt} \%$ with a moderate increase in $\mathrm{Al}_{2} \mathrm{O}_{3}$ to $19.5 \mathrm{wt} \%$ (Fig. 8a). $\mathrm{K}_{2} \mathrm{O}$ remains constant during this step. Removal of hornblendite additionally explains the observed decrease in $\mathrm{TiO}_{2}$ at intermediate $\mathrm{SiO}_{2}$, as hornblendites are enriched in $\mathrm{TiO}_{2}$ (up to $2 \mathrm{wt} \%$ ) (Fig. 8b). After fractionation of hornblendite, hbl-bearing gabbro crystallization suppresses further increase in $\mathrm{Al}_{2} \mathrm{O}_{3}$ due to the appearance of plagioclase in the assemblage. The increase in $\mathrm{SiO}_{2}$ induced by hornblendite fractionation is further amplified by the fractionation of hornblende gabbro (45 wt \%) that efficiently leads to the generation of $\mathrm{SiO}_{2}$-rich derivative liquids (63 wt\%) (Fig. 8). $\mathrm{Na}_{2} \mathrm{O}$ increases continuously during gabbro fractionation, whereas $\mathrm{K}_{2} \mathrm{O}$ slightly decreases. Hornblende gabbro has similar $\mathrm{TiO}_{2}$ content as hornblendite, thus $\mathrm{TiO}_{2}$ continues to decrease with increasing $\mathrm{SiO}_{2}$ (Fig. 8b). Fractionation of diorite (step 5) drives the $\mathrm{SiO}_{2}$ content of derivative liquids to more than $70 \mathrm{wt} \%$ at constant $\mathrm{Al}_{2} \mathrm{O}_{3}$ and straddles the metaluminous-peraluminous boundary (Fig. 8c). Because of the existence of tonalite with a positive Eu anomaly, we inferred that small amounts of tonalite were additionally removed at the end of the sequence. The role of tonalite is not of critical importance in these models as it does not change the final liquids significantly.

\section{Trace element modeling}

The trace and REE modeling are more sensitive to the choice of an appropriate starting composition (Fig. 9) and to the chemistry of the fractionating assemblage than for major elements, because variations observed within the same group of rocks could be significant (Fig. 9). Simple mass balance calculation has the advantage to be independent on the choice of Kd's and includes all minor phases potentially present in the samples which could dramatically change the bulk distribution coefficient. As no constraints exist for the parental melt, the model was performed using two different starting compositions within the range of variations observed in actual arc lavas (Kelemen et al. 2003) and could reproduce the trend for the trace elements and REE (Table 4).

\section{Chemical effect of cumulates}

The trace and REE concentration variations within each type of rocks could be important particularly in hornblendite/pyroxene hornblendite. Hornblendites have extremely different REE patterns (e-fig. 2) that vary with differentiation; at high $\mathrm{Mg}^{\sharp}$, they contain a less evolved signature
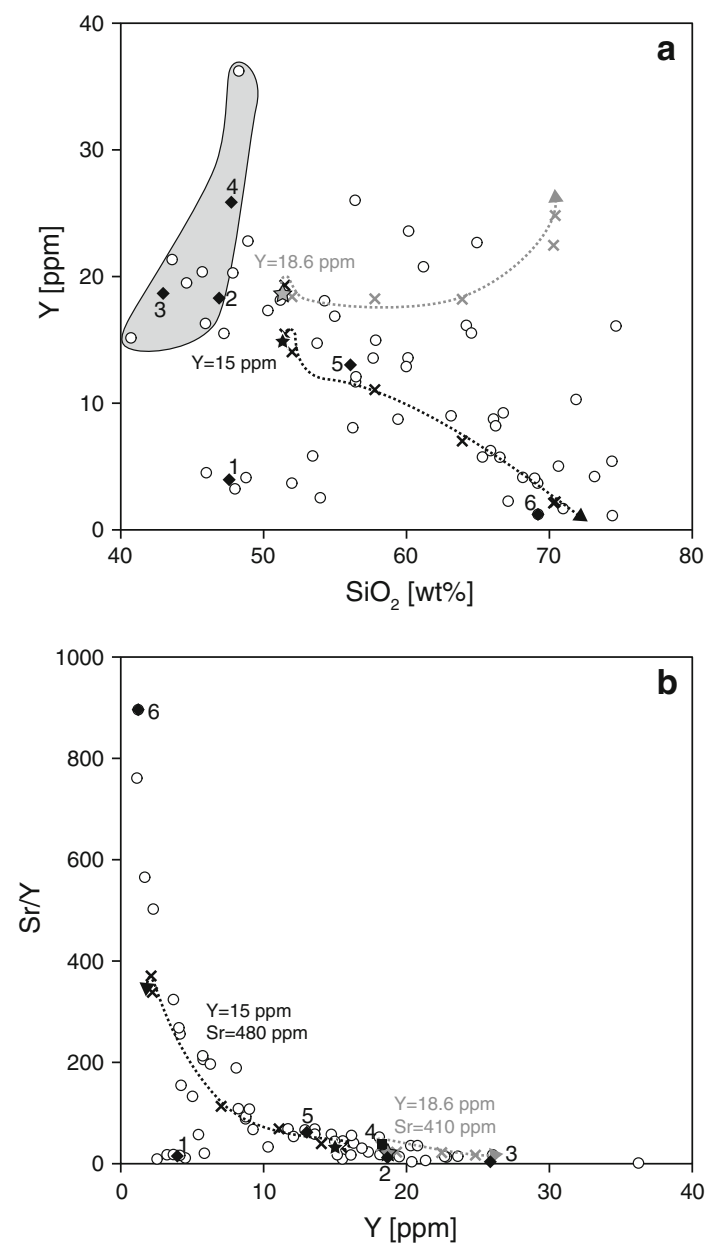

Fig. 9 Comparison of the results of modeling and whole rocks chemistry for selected trace elements and trace element ratios. The modeling evaluated different starting compositions. The gray arrow corresponds to the model using average continental arc composition (Kelemen et al. 2003) as starting composition. The black arrow corresponds to the model using a starting composition selected within the range of actual active arc primitive lavas to evaluate the role of the parental liquid compositions. The gray field illustrates the variability of hornblende-hornblende-pyroxenite compositions of the Chelan Complex

(e.g., low Y, absence of Eu anomaly), whereas at low $\mathrm{Mg}^{\sharp}$ they contain a more evolved signature (high $Y$ content, negative Eu anomaly). This suggest a protracted crystallization of hornblendite/pyroxene hornblendite during the differentiation and that hornblende (and less likely pyroxene) continues to be extracted after plagioclase appears on the liquidus (negative $\mathrm{Eu}$ anomaly). Amphibole (or pyroxene), therefore, crystallizes from a progressively more evolved melt. The variations observed within the hornblendite group are important for $Y$ and REE (15-36 ppm $Y$ ) and are coherent with the change observed in experimentally determined partition coefficient with increasing differentiation (Tiepolo et al. 2007) (Fig. 9). The choice of the appropriate chemistry during hornblendite 
fractionation is crucial to reproduce the trend for REE and $Y$. However, no constraint exists on the relative occurrence of high- over low- $Y$ (pyroxene) hornblendite and on a possible continuity between them. The presence of hornblendite/pyroxene hornblendite having as much as $36 \mathrm{ppm}$ of $\mathrm{Y}$, nevertheless, suggests that $Y$-rich cumulates were involved in the differentiation. The decrease in $Y$ and HREE reflects the amphibole signature, which incorporates increasing HREE and $Y$ as the melt evolves toward higher $\mathrm{SiO}_{2}$ (Fig. 6b). It is, thus, not necessary to fractionate garnet in order to obtain Sr-rich, $Y$ - and REE-depleted rocks, in the Chelan Complex.

Model prediction versus experimental prediction: volume constraint

Recent experiments performed at different pressures and water contents simulating potential condition of magma emplacement in active margin settings may provide useful informations on the fractionating assemblages and on their volumes upon crystallization-driven differentiation. As the Chelan Complex is inferred to be emplaced around 1.0 $\mathrm{GPa}$, the model and whole rock chemistry are compared to the fractional crystallization experiments performed on a high $\mathrm{Mg}^{\sharp}$ basaltic andesite by Kägi (2000) at $1.0 \mathrm{GPa}$ for the most primitive cumulates, whereas the more evolved path is compared to the experimental study of Sisson et al. (2005) on low $\mathrm{K}$ basalt at $0.7 \mathrm{GPa}$ close to the FMQ oxygen buffer.

In the experimental study of a basaltic andesite at 1.0 $\mathrm{GPa}$, the sequence of crystallization is orthopyroxene $\rightarrow$ orthopyroxene + clinopyroxene $\rightarrow$ clinopyroxene + amphibole (Kägi 2000), whereas in the Chelan Complex, the sequence is olivine + clinopyroxene $\rightarrow$ clinopyroxene + amphibole $\rightarrow$ amphibole. The difference at the beginning is explained by the different starting composition between experiment and parental liquid used for modeling. Actually, the starting composition used by Kägi (2000) lies in the primary field of orthopyroxene (Fig. 10), although the parental liquid lies almost on the experimentally determined cotectic lines of clinopyroxene and olivine. The proximity of the parental melt to the multiple saturation implies that only very little olivine will crystallize, in agreement with field observations where olivine and pyroxene bearing rocks are rare and in agreement with the model where only a few percent of olivine websterite is removed. The rare occurrence of orthopyroxene bearing rocks in the Chelan Complex may be the result of higher water contents in the melt which tends to stabilize clinopyroxene relative to orthopyroxene (Müntener et al. 2001). The appearance of amphibole occurs through peritectic reactions consuming orthopyroxene or clinopyroxene at high temperature (Kägi 2000), and the stability field of

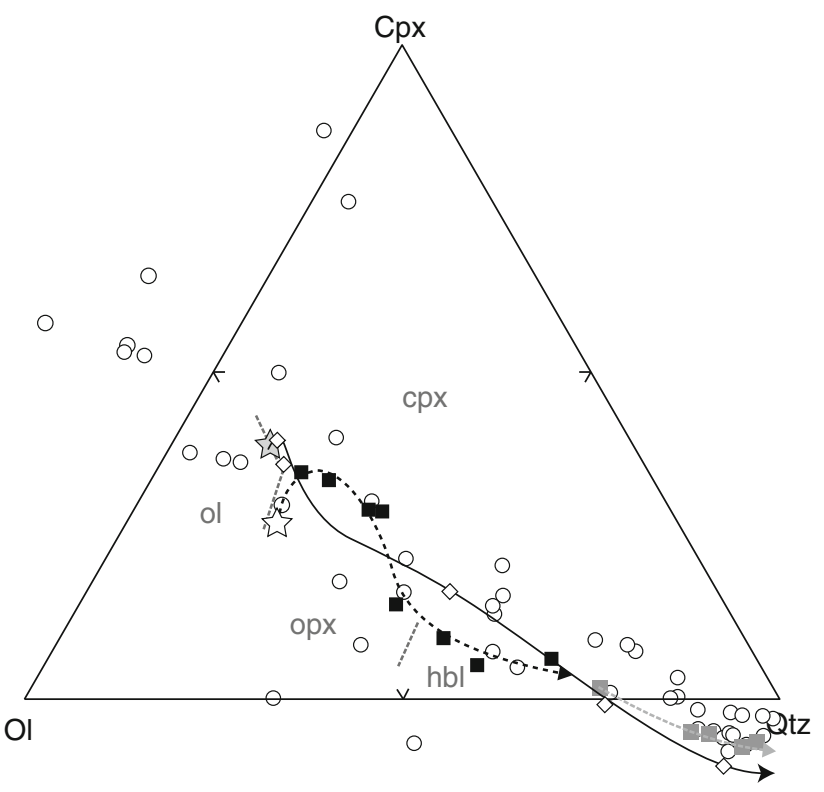

Fig. 10 Normative, pseudoternary olivine-cpx-quartz projection after Grove (1993). Whole rock analyses (open circles) and major element modeling (open diamond) are compared to the liquid line of descent for fractional crystallization experiment at $1.0 \mathrm{GPa}$ conducted under water-bearing conditions (black-dotted arrow and black squares) using high $\mathrm{Mg}^{\sharp}$ andesite as starting material (open star, Kägi 2000) and to the liquid line of descent for experiments conducted at $0.7 \mathrm{GPa}$ and an $\mathrm{fO}_{2}$ close to FMQ, employing a low $K$ basalt as starting material (gray-dotted arrow and gray square) (Sisson et al. 2005). The gray star represents the liquid composition used as starting composition in the major and trace element modeling (Kelemen et al. 2003). The plain black arrow connects the open diamonds that are the result of crystal fractionation modeling. The gray-dotted line indicates mineral stability fields (Kägi 2000)

amphibole is dependent on different factors such as pressure, water content and $\mathrm{Na}_{2} \mathrm{O} / \mathrm{K}_{2} \mathrm{O}$ in the melt, which will expand or contract the stability field of amphibole (e.g., Sisson and Grove 1993a, b). The fractionation path at 1.0 $\mathrm{GPa}$ down to $990^{\circ} \mathrm{C}$ reaches derivative melt compositions around $58 \mathrm{wt} \% \mathrm{SiO}_{2}$ just prior to the saturation of plagioclase (Kägi 2000). The volume of ultramafic cumulates obtained in the experiments is approximately $44 \%$ of the total volume (remaining liquid is therefore 56\%). Although the sequence of crystallization is somewhat different in the Chelan Complex, the volume obtained is roughly similar for ultramafic cumulates $(49 \%)$ as well as for the $\mathrm{SiO}_{2}$ content of the derivative melt $(\sim 57.5)$ and for other oxides (Table 4), with the noteworthy exception of $\mathrm{Al}_{2} \mathrm{O}_{3}$ reaching higher values in the experiments $(\sim 21 \mathrm{wt} \%)$ compared to the model $(\sim 18.5 \mathrm{wt} \%)$ (Fig. 8). The highest $\mathrm{Al}_{2} \mathrm{O}_{3}$ reflects the late saturation of amphibole in the experiment compared to the Chelan Complex. Sisson et al. (2005) performed experiments on water-saturated basalt at intermediate pressure of $0.7 \mathrm{GPa}$ and explored the genesis of high silica rocks under different $\mathrm{fO}_{2}$ conditions. These experiments provide the link between ultramafic and mafic 
cumulates. The variations of major elements, especially the decrease in $\mathrm{Al}_{2} \mathrm{O}_{3}$, follow the trend obtained experimentally by Sisson et al. (2005) at $0.7 \mathrm{GPa}$ at $\mathrm{fO}_{2}$ close to FMQ buffer. The high $\mathrm{Na}_{2} \mathrm{O} / \mathrm{K}_{2} \mathrm{O}$ in the Chelan Complex is different from the experiments, leading to a different fractionation sequence obtained in the experiments than in the field. Amphibole is stabilized rather than plagioclase because of the high $\mathrm{Na}_{2} \mathrm{O} / \mathrm{K}_{2} \mathrm{O}$ ratio and the high water content in the melt. However, a low $\mathrm{K}$ series does not saturate biotite because of low $\mathrm{K}$ in the starting composition, the behavior of $\mathrm{K}_{2} \mathrm{O}$ is not reliably applicable to the Chelan Complex. Nevertheless, the experiments of Sisson et al. (2005) provide a link between the fractional crystallization experiment at $1.0 \mathrm{GPa}$ under hydrous conditions and the generation of peraluminous tonalite (Fig. 10). Coupled together, the experiments relate primitive arc basalt and peraluminous tonalite by crystal fractionation processes. The Chelan Complex exhibits the same behavior as the combination of both sets of experiments utilizing major element chemistry and textural observations. Thus, we conclude that the chemistry and textural relationships of the Chelan Complex is the product of crystal fractionation at high pressure of a wet mafic magma and is not the product of partial melting.

Tectonic history of Chelan Complex in the framework of North Cascades Core

The North Cascades Core underwent a complex tectonic history since late Jurassic/early Cretaceous associated with metamorphic and magmatic events (e.g., Paterson et al. 2004; Valley et al. 2003; Whitney 1992) that partially obliterated the early history. The Chelan Complex is the oldest magmatic member of the Chelan block. U-Pb dating on zircon yields crystallization ages ranging from 100 to $120 \mathrm{Ma}$ (Mattinson 1972; Tabor et al. 1987; Hopson and Mattinson 1994) which is sensibly older than other plutonic rocks within the North Cascades Core (typically emplaced between 96 and 40 Ma (e.g., Miller et al. 2009)) and is closer in time to the Okanogan batholith (111-114 Ma (Hurlow and Nelson 1993)) that is exposed in the North of the Chelan block. However, the nature of the contact between the Chelan Complex and Okanogan batholith is obscured and not well constrained (Hopson and Mattinson 1994; Haugerud and Tabor 2009). Due to the proximity of the Ross Lake fault Zone, it may be of tectonic origin (Hopson and Mattinson 1994; Haugerud and Tabor, 2009). Nevertheless, the lateral displacement of the Ross Lake fault is limited $(<10 \mathrm{~km})$ (Umhoefer and Miller 1996), and the similarity in age between the two units indicates that the Chelan Complex could be the Spence Bridge arc, which was active during the early Cretaceous (Thorkelson and Smith 1989; Hurlow and Nelson 1993). The position of the
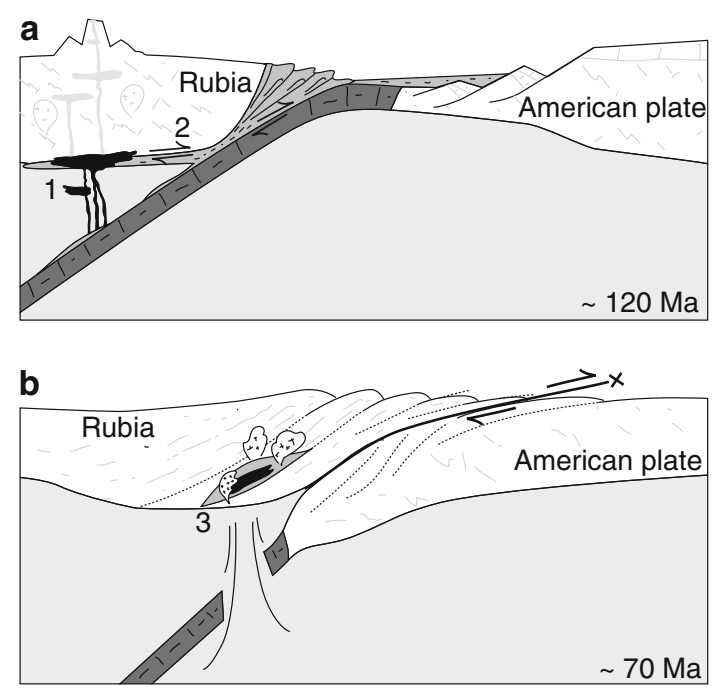

Fig. 11 Sketches illustrating the evolution of the Chelan Complex in the tectonic framework of the Cordillera, model and name of terranes were taken from Hildebrand (2009). The sketches are not at scale and are only conceptual; a The Napeequa unit is underthrust beneath Rubia (1) and is intruded by the Chelan Complex (2) at the base of late Jurassic/early Cretaceous volcanic arcs due to the westward subduction of the American plate. b Intrusion of the Entiat pluton (3) between the Nappequa unit and the Chelan Complex which are still located in the lower part of the crust (pressure of 0.6-0.7 GPa, equivalent to $\sim 20 \mathrm{~km}$. The Entiat pluton could be related to the break off of the down-going slab

arc relative to the American craton could vary between different studies (1) west facing magmatic arc on the intermontane superterrane already accreted to the American craton due to eastward subduction (Thorkelson and Smith 1989; Hurlow and Nelson 1993), (2) east facing magmatic arc on an exotic terrane (Rubia) due to westward subduction of the American plate (Johnston 2008; Hildebrand 2009) (Fig. 11a). Whereas the position is different, the timing of arc formation is sensibly similar between different models and initiated around $120 \mathrm{Ma}$. The age of the Chelan Complex is in agreement with the age of the arc, and the context is coherent with field, textural and chemical observations to explain the emplacement of the complex at the base of a volcanic arc at pressures ranging around 1.0 GPa (Fig. 11). The contact between the Chelan Complex and the host country rocks, the Napeequa unit to the west and the Cascade River Holden Twenty-Five Miles Creek unit to the north is poorly exposed. However, some field evidence along the exposed contacts indicates that the Chelan Complex is intrusive in both units (Hopson and Mattinson 1994). As the subsolidus pressure and temperature estimated for the Chelan Complex $(\sim 1.0 \mathrm{GPa}$, $\sim 750^{\circ} \mathrm{C}$ ) is similar to the temperature obtained in the pelitic schist of the Napeequa unit $\left(1.0-1.1 \mathrm{GPa}, 750^{\circ} \mathrm{C}\right.$ (Valley et al. 2003)), the Napeequa unit should be at similar depth during the intrusion of the Chelan Complex. 
This implies that the crust at the time of intrusion was at least $\sim 30 \mathrm{~km}$ thick (Fig. 11a). The timing of burial of the Napeequa unit might be sensibly older than suggested by previous studies, which constrained the time of the metamorphic peak to be older than or around $96 \mathrm{Ma}$, based on the lack of high-pressure intrusive rocks older than $96 \mathrm{Ma}$ within the unit (Valley et al. 2003). The Chelan Complex is cut by the Entiat pluton, which partially obliterates the contact with the host and which was emplaced at pressures of 0.6-0.7 GPa (Paterson et al. 1998) between 73 and $67 \mathrm{Ma}$ (Paterson et al. 2004). The time and pressure of emplacement indicate that the Chelan Complex was still located deep in the crust $(\sim 20 \mathrm{~km})$ during the intrusion of the Entiat pluton (Fig. 11b). Therefore, the Chelan Complex remained at least 30-35 Ma at pressures exceeding or equal to $0.6 \mathrm{GPa}$. This long residence time in the crust explains the widespread isobaric cooling observed within the rocks of the Chelan Complex. The exhumation history of the North Cascades Core is complex and different along North-South and East-West directions (Paterson et al. 2004, for a thorough discussion of the exhumation history). Sparse sphene and hornblende cooling ages of the Chelan Complex suggest cooling below $500^{\circ} \mathrm{C}$ occurred around $60 \mathrm{Ma}$ (Mattinson 1972; Tabor et al. 1987) and have a common cooling path with the Napeequa unit (Matzel 2004). At the same time, the Skagit gneiss to the North was buried and underwent a migmatitic event (Wernicke and Getty 1997; Whitney et al. 1999; Matzel et al. 2008). The Chelan Complex and the Napeequa unit do not record late Cretaceous/early Tertiary burial, but were already exhumed at this time (Paterson et al. 2004). Finally, the Chelan Complex reached the surface around $45 \mathrm{Ma}$ ago together with the other rocks of the Cascades Core (Hopson and Mattinson 1994; Paterson et al. 2004).

\section{Concluding remarks}

The Chelan Complex is a key area to understand the processes occurring in deep magma reservoirs above subduction zones. It underlines the long emplacement history and igneous activity of such a system and cools slowly in the crust at intermediate pressures. Despite subsolidus and isobaric cooling processes obliterating foregoing magmatic processes, some traces of the magmatic stage are well preserved and were used to understand the primary processes of differentiation at low to middle crustal levels. The Chelan Complex is an example for amphibole crystallization and accumulation representing the principal process of differentiation at intermediate pressure that is often referred to as cryptic amphibole formation to explain the chemistry of arc lavas (Davidson et al. 2007). Amphibole controls the chemistry of the complex for major and trace elements over a considerable part of the differentiation path. Amphibole fractionation is, furthermore, capable of generating slightly peraluminous tonalite (Müntener et al. 2001; Sisson et al. 2005) without involving a sedimentary source or crustal contamination. Amphibole fractionation and delay of plagioclase saturation could lead to adakitic signatures, without invoking slab melting or garnet residues in the source. Thus, fractionation and accumulation of amphibole from a wet basaltic magma at intermediate pressure are important in the generation of the continental crust and rely liquids in equilibrium with the mantle and the composition of the continental crust. Due to density difference between hornblende cumulates compared to the mantle, it seems not likely that amphibole-rich cumulates return to the mantle by delamination unless they form garnet by metamorphic reactions. The observed difference between the bulk composition of the continental crust and mantle-derived basalts could be resolved by large amount of hornblende cumulates trapped in the lower crust. Amphibole fractionation provides the link between surface volcanism above active margins and deep-seated differentiation leading to andesitic/rhyolitic compositions exposed in shallow level plutons and in the volcanic edifices.

Acknowledgments This study was funded by the Swiss National Foundation grant 200021-210054. Installation of the Element XR facility at UNIL was supported by SNF grant 206021-117405. We would like to thank Laurent Nicod for thin sections preparation, JeanClaude Lavanchy for XRF measurements; Alexey Ulianov for the time invested to optimize the LA-ICP-MS instrument; James Allibon and Franois Bussy for granting time access to the microprobe. Olivier Bachmann and Georges Bergantz, Seattle, U.S.A for hospitality, the Public Utility District of the Chelan county, especially Rob Campbell, Chelan U.S.A and Eric Degman, Wenatchee, U.S.A allowing the visit of the amazing Chelan gorge without flooding us. Finally, we thank G. Bergantz and D. Canil for constructive reviews.

\section{References}

Alonso-Perez R, Müntener O, Ulmer P (2009) Igneous garnet and amphibole fractionation in the roots of island arcs: experimental constraints on andesitic liquids. Contrib Mineral Petrol 157(4):541-558

Arculus R, Wills K (1980) The petrology of plutonic blocks and inclusions from the Lesser Antilles island arc. J Petrol 21(4):743-799

Atherton M, Petford N (1996) Plutonism and the growth of Andean crust at $9 \mathrm{~S}$ from 100 to 3 Ma. J South Am Earth Sci 9(1-2):1-9

Brown E, Walker N (1993) A magma-loading model for Barrovian metamorphism in the southeast Coast Plutonic Complex, British Columbia and Washington. Geol Soc Am Bull 105:479

Burg J, Bodinier J, Chaudhry S, Hussain S, Dawood H (1998) Infraarc mantle-crust transition and intra-arc mantle diapirs in the Kohistan Complex (Pakistani Himalaya): petro-structural evidence. Terra Nova 10:74-80

Cawthorn R, Curran E, Arculus R (1973) A petrogenetic model for the origin of the calc-alkaline suite of Grenada, Lesser Antilles. J Petrol 14(2):327-337

Cox KG (1979) The interpretation of igneous rocks. George Allen and Unwin, London 
Davidson J, Turner S, Handley H, Macpherson C, Dosseto A (2007) Amphibole "sponge" in arc crust?. Geology 35(9):787-790

DeBari SM, Coleman RG (1989) Examination of the deep levels of an island arc: evidence from the Tonsina ultramafic-mafic assemblage, Tonsina, Alaska. J Geophys Res 94(4):4373-4391

DeBari SM, Sleep NH (1991) High-Mg, low-Al bulk composition of the Talkeetna island arc, Alaska; implications for primary magmas and the nature of arc crust. Geol Soc Am Bull 103(1):37-47

Defant M, Drummond M (1990) Derivation of some modern arc magmas by melting of young subducted lithosphere. Nature 347(6294):662-665

Ducea M, Saleeby J (1996) Buoyancy sources for a large, unrooted mountain range, the Sierra Nevada, California: evidence from xenolith thermobarometry. J Geophys Res 101:8229-8244

Ducea M, Saleeby J (1998) The age and origin of a thick maficultramafic keel from beneath the Sierra Nevada batholith. Contrib Mineral Petrol 133(1):169-185

Ernst W, Liu J (1998) Experimental phase-equilibrium study of Aland Ti-contents of calcic amphibole in MORB-A semiquantitative thermobarometer. Am Mineral 83:952-969

Feig ST, Koepke J, Snow JE (2006) Effect of water on tholeiitic basalt phase equilibria: an experimental study under oxidizing conditions. Contrib Mineral Petrol 152(5):611-638

Giere R, Sorensen S (2004) Allanite and other REE-rich epidotegroup minerals. Rev Mineral Geochem 56(1):431-493

Gordon S, Whitney D, Miller R, McLean N, Seaton N (2010) Metamorphism and deformation at different structural levels in a strike-slip fault zone, Ross Lake fault, North Cascades, USA. J Metamorph Geol 28(2):117-136

Green D, Ringwood A (1967) The genesis of basaltic magmas. Contrib Mineral Petrol 15(2):103-190

Greene AR, DeBari SM, Kelemen PB, Blusztajn J, Clift PD (2006) A detailed geochemical study of island arc crust: the Talkeetna arc section, South-Central Alaska. J Petrol 47(6):1051-1093

Grove T (1993) Corrections to expressions for calculating mineral components in "Origin of calc-alkaline series lavas at Medicine Lake Volcano by fractionation, assimilation and mixing" and "Experimental petrology of normal MORB near the Kane fracture zone: $22^{\circ}-25^{\circ} \mathrm{N}$, mid-Atlantic ridge". Contrib Mineral Petrol 114(3):422-424

Grove T, Parman S, Bowring S, Price R, Baker M (2002) The role of an $\mathrm{H}_{2} \mathrm{O}$-rich fluid component in the generation of primitive basaltic andesites and andesites from the Mt. Shasta region, N California. Contrib Mineral Petrol 142(4):375-396

Haugerud R, Tabor R (2009) Geologic map of the North Cascade Range, Washington

Haugerud R, van der Heyden P, Tabor R, Stacey J, Zartman R (1991) Late Cretaceous and early Tertiary plutonism and deformation in the Skagit Gneiss Complex, North Cascade Range, Washington and British Columbia. Geol Soc Am Bull 103:1297-1307

Hildebrand R (2009) Did westward subduction cause CretaceousTertiary orogeny in the North American Cordillera?. GSA Special Papers 457:1-71

Hildreth W, Moorbath S (1988) Crustal contributions to arc magmatism in the Andes of central Chile. Contrib Mineral Petrol 98(4):455-489

Holland T, Blundy J (1994) Non-ideal interactions in calcic amphiboles and their bearing on amphibole-plagioclase thermometry. Contrib Mineral Petrol 116(4):433-447

Hopson CA, Mattinson JM (1994) Chelan Migmatite Complex, Washington: field evidence for mafic magmatism, crustal anatexis, mixing and protodiapiric emplacement. In: Geologic Field Trips in the Pacific Northwest: 1994 Geological Society of America Annual Meeting. Seattle, WA, pp 1-21
Hurlow H, Nelson B (1993) U-Pb zircon and monazite ages for the Okanogan Range batholith, Washington: Implications for the magmatic and tectonic evolution of the southern Canadian and northern United States Cordillera. Geol Soc Am Bull 105(2):231-240

Jackson S (2008) Appendix Al: Lamtrace data reduction software for LA-ICP-MS. Laser ablation-ICP-MS in the earth sciences: current practices and outstanding issues, pp 305-307

Jagoutz O (2010) Construction of the granitoid crust of an island arc. Part II: a quantitative petrogenetic model. Contrib Mineral Petrol 160(3): $1-23$

Jagoutz O, Müntener O, Ulmer P, Pettke T, Burg J, Dawood H, Hussain S (2007) Petrology and mineral chemistry of lower crustal intrusions: the Chilas Complex, Kohistan (NW Pakistan). J Petrol 48(10):1895-1953

Johnston S (2008) The cordilleran ribbon continent of North America. Annu Rev Earth Planet Sci 36:495-530

Journeay J, Friedman R (1993) The coast belt thrust system: evidence of late cretaceous shortening in southwest British Columbia. Tectonics 12(3):756-775

Jull M, Kelemen PB (2001) On the conditions for lower crustal convective instability. J Geophys Res 106(B4):6423-6446

Kägi R (2000) The liquid line of descent of hydrous, primary, calcalkaline magmas under elevated pressure. an experimental approach. PhD thesis, ETH Zürich, p 100

Kay R, Kay SM (1991) Creation and destruction of lower continental crust. Geol Rund 80(2):259-278

Kay RW, Kay SM (1993) Delamination and delamination magmatism. Tectonophysics 219(1-3):177-189

Kay S, Kay RW (1985) Role of crystal cumulates and the oceanic crust in the formation of the lower crust of the Aleutian arc. Geology 13(7):461-464

Kelemen P, Hanghøj K, Greene A (2003) One view of the geochemistry of subduction-related magmatic arcs, with an emphasis on primitive andesite and lower crust. Treatise Geochem 3:593-659

Kessel R, Ulmer P, Pettke T, Schmidt M, Thompson A (2005) The water-basalt system at 4 to $6 \mathrm{GPa}$ : Phase relations and second critical endpoint in a K-free eclogite at 700 to $1400 \mathrm{C}$. Earth Planet Sci Lett 237(3-4):873-892

Klimm K, Blundy J, Green T (2008) Trace element partitioning and accessory phase saturation during $\mathrm{H}_{2} \mathrm{O}$-saturated melting of basalt with implications for subduction zone chemical fluxes. $\mathrm{J}$ Petrol 49(3):523-553

Kushiro I, Syono Y, Akimoto S (1968) Melting of a peridotite nodule at high pressures and high water pressures. J Geophys Res 73(18):6023-6029

Larocque J, Canil D (2010) The role of amphibole in the evolution of arc magmas and crust: the case from the Jurassic Bonanza arc section, Vancouver Island, Canada. Contrib Mineral Petrol 159(4): $1-18$

Leake BE, Woolley AR, Arps CE, Birch WD, Gilbert MC, Grice JD, Hawthorne FC, Kato A, Kisch HJ, Krivovichev VG et al (1997) Nomenclature of amphiboles; report of the subcommittee on amphiboles of the international mineralogical association, commission on new minerals and mineral names. Can Mineral 35(1):219-246

Lindsley D (1983) Pyroxene thermometry. Am Mineral 68(5-6):477_ 493

Macpherson C (2008) Lithosphere erosion and crustal growth in subduction zones: Insights from initiation of the nascent East Philippine Arc. Geology 36(4):311-314

Mattinson JM (1972) Ages of zircons from the northern Cascade Mountains, Washington. Geol Soc Am Bull 83(12):3769-3784

Matzel J, Bowring S, Miller R (2008) Spatial and temporal variations in Nd isotopic signatures across the crystalline core of the North Cascades, Washington. GSA Special Papers 438:499-516 
Matzel JEP (2004) Rates of Tectonic and Magmatic processes in the North Cascades Continental Magmatic Arc. PhD thesis, MIT

McDonough W, Sun S (1995) The composition of the Earth. Chem Geol 120(3-4):223-253

Mehnert K (1968) Migmatites and the origin of granitic rocks. Elsevier Science Publ B.V., Amsterdam

Miller R, Gordon S, Bowring S, Doran B, McLean N, Michels Z, Shea E, Whitney D, Wintzer N, Mendoza M (2009) Linking deep and shallow crustal processes in an exhumed continental arc, North Cascades, Washington. Volcanoes to Vineyards: Geologic Field Trips Through the Dynamic Landscape of the Pacific Northwest, pp 373-404

Miller RB, Paterson SR (2001) Construction of mid-crustal sheeted plutons: examples from the North Cascades, Washington. Geol Soc Am Bull 113(11):1423-1442

Miller RB, Paterson SR, DeBari SM, Whitney DL (2000) North Cascades Cretaceous crustal section: Changing kinematics, rheology, metamorphism, pluton emplacement and petrogenesis from 0 to $40 \mathrm{~km}$ depth. Guidebook for geological field trips in southwestern British Columbia and northern Washington: geological association of Canada, cordilleran section, pp 229-278

Miyashiro A (1974) Volcanic rock series in island arcs and active continental margins. Am J Sci 274(4):321-355

Müntener O, Ulmer P (2006) Experimentally derived high-pressure cumulates from hydrous arc magmas and consequences for the seismic velocity structure of lower arc crust. Geophys Res Lett 33:L21308

Müntener O, Hermann J, Trommsdorff V (2000) Cooling history and exhumation of lower-crustal granulite and upper mantle (Malenco, Eastern Central Alps). J Petrol 41(2):175-200

Müntener O, Kelemen PB, Grove TL (2001) The role of $\mathrm{H}_{2} \mathrm{O}$ during crystallization of primitive arc magmas under uppermost mantle conditions and genesis of igneous pyroxenites: an experimental study. Contrib Mineral Petrol 141(6):643-658

Paterson S, Miller R, Alsleben H, Whitney D, Valley P, Hurlow H (2004) Driving mechanisms for $>40 \mathrm{~km}$ of exhumation during contraction and extension in a continental arc, Cascades core, Washington. Tectonics 23(3):TC3005

Paterson SR, Fowler TK, Schmidt KL, Yoshinobu AS, Yuan ES, Miller RB (1998) Interpreting magmatic fabric patterns in plutons. Lithos 44(1-2):53-82

Pearce N, Perkins W, Westgate J, Gorton M, Jackson S, Neal C, Chenery S (1997) A compilation of new and published major and trace element data for NIST SRM 610 and NIST SRM 612 glass reference materials. Geostand Newslett 21:115-144

Petford N, Atherton M (1996) Na-rich partial melts from newly underplated basaltic crust: the Cordillera Blanca Batholith, Peru. J Petrol 37(6):1491-1521

Pichavant M, Mysen BO, Macdonald R (2002) Source and $\mathrm{H}_{2} \mathrm{O}$ content of high-MgO magmas in island arc settings: an experimental study of a primitive calc-alkaline basalt from St. Vincent, Lesser Antilles arc. Geochim Cosmochim Acta 66(12):2193-2209

Ringuette L, Martignole J, Windley B (1999) Magmatic crystallization, isobaric cooling, and decompression of the garnet-bearing assemblages of the Jijal Sequence (Kohistan Terrane, western Himalayas). Geology 27(2):139-143

Rubin CM, Saleeby JB, Cowan DS, Brandon MT, McGroder MF (1990) Regionally extensive mid-Cretaceous west-vergent thrust system in the northwestern cordillera; implications for continentmargin tectonism. Geology 18(3):276-280

Rudnick RL (1995) Making continental crust. Nature 378(6557):571578

Rudnick RL, Gao S (2003) Composition of the continental crust. Treatise Geochem 3:1-64
Sawyer E (2008) Atlas of migmatites. The Canadian Mineralogist Special Publication, Canada

Schmidt M, Poli S (2004) Magmatic epidote. Rev Mineral Geochem 56(1):399-430

Sisson TW, Grove TL (1993) Experimental investigations of the role of $\mathrm{H}_{2} \mathrm{O}$ in calc-alkaline differentiation and subduction zone magmatism. Contrib Mineral Petrol 113(2):143-166

Sisson TW, Grove TL (1993) Temperatures and $\mathrm{H}_{2} \mathrm{O}$ contents of low$\mathrm{MgO}$ high-alumina basalts. Contrib Mineral Petrol 113(2):167-184

Sisson TW, Ratajeski K, Hankins WB, Glazner AF (2005) Voluminous granitic magmas from common basaltic sources. Contrib Mineral Petrol 148(6):635-661

Tabor RW, Jr VAF, Whetten JT, Waitt RB, Swanson DA, Byerly GR, Booth DB, Hetherington MJ, Zartman RE (1987) Geologic map of the Chelan 30-min by 60-min quadrangle, Washington. US Geological Survey, Miscellaneous Investigation Series

Tatsumi Y (1989) Migration of fluid phases and genesis of basalt magmas in subduction zones. J Geophys Res 94(B4):4697-4707

Taylor S, McLennan S (1985) Continental crust: its composition and evolution. Blackwell, Oxford

Thorkelson D, Smith A (1989) Arc and intraplate volcanism in the Spences Bridge Group: Implications for Cretaceous tectonics in the Canadian Cordillera. Geology 17(12):1093-1096

Tiepolo M, Oberti R, Zanetti A, Vannucci R, Foley S (2007) Traceelement partitioning between Amphibole and Silicate Melt. Rev Mineral Geochem 67:417-452

Ulmer P (2007) Differentiation of mantle-derived calc-alkaline magmas at mid to lower crustal levels: experimental and petrologic constraints. Per Mineral 76(2-3):309-325

Ulmer P, Trommsdorff V (1995) Serpentine stability to mantle depths and subduction-related magmatism. Science 268(5212):858-861

Umhoefer PJ, Miller RB (1996) Mid-Cretaceous thrusting in the southern Coast Belt, British Columbia and Washington, after strike-slip fault reconstruction. Tectonics 15(3):545-565

Valley PM, Whitney DL, Paterson SR, Miller RB, Alsleben H (2003) Metamorphism of the deepest exposed arc rocks in the Cretaceous to Paleogene Cascades belt, Washington: evidence for large-scale vertical motion in a continental arc. J Metamorph Geol 21(2):203-220

Wells P (1977) Pyroxene thermometry in simple and complex systems. Contrib Mineral Petrol 62(2):129-139

Wernicke B, Getty S (1997) Intracrustal subduction and gravity currents in the deep crust: Sm-Nd, Ar-Ar, and thermobarometric constraints from the Skagit Gneiss Complex, Washington. Geol Soc Am Bull 109(9):1149

Whitney DL (1992) Origin of $\mathrm{CO}_{2}$-rich fluid inclusions in leucosomes from the Skagit migmatites, North Cascades, Washington, USA. J Metamorph Geol 10(6):715-725

Whitney DL, Miller RB, Paterson SR (1999) PTt evidence for mechanisms of vertical tectonic motion in a contractional orogen: north-western US and Canadian Cordillera. J Metamorph Geol 17(1):75-90

Zen E, Hammarstrom JM (1984) Magmatic epidote and its petrologic significance. Geology 12(9):515-518

Zen E, Hammarstrom JM (1986) Comments and Reply on "Implications of magmatic epidote-bearing plutons on crustal evolution in the accreted terranes of northwestern North America" and "Magmatic epidote and its petrologic significance". Geology 14(2):188-189

Zen Ea (1985) Implications of magmatic epidote-bearing plutons on crystal evolution in the accreted terranes of northwestern North America. Geology 13(4):266-269

Zen Ea (1986) Aluminum enrichment in silicate melts by fractional crystallization: some mineralogic and petrographic constraints. J Petrol 27(5):1095-1117 